\title{
OPEN-AIR DEPOSITION OF ESTONIAN OIL SHALE ASH: FORMATION, STATE OF ART, PROBLEMS AND PROSPECTS FOR THE ABATEMENT OF ENVIRONMENTAL IMPACT
}

\author{
REIN KUUSIK $^{(a)}$, MAI UIBU $^{(\mathrm{a})^{*}}$, KALLE KIRSIMÄE $^{(\mathrm{b})}$, \\ RIHO MÕTLEP(b) TÕNIS MERISTE ${ }^{(\mathrm{c})}$
}

(a) Laboratory of Inorganic Materials, Tallinn University of Technology, Ehitajate tee 5, 19086 Tallinn, Estonia

(b) Department of Geology, University of Tartu, Ravila 14a, 50411 Tartu, Estonia

(c) Eesti Energia AS, Laki 24, 12915 Tallinn, Estonia

\begin{abstract}
The growing demand for the world energy supply necessitates the employment of local low-grade fossil fuels like oil shale (OS). The use of such fuels is accompanied by the formation of large amounts of waste ash, which are usually disposed of in open-air deposits and may hence lead to serious environmental problems. The nature of environmental hazards depends on the composition and properties of the deposited ash, which in turn are derived from the composition of the initial fuel, as well as its processing parameters. The exploitation of Estonian OS deposits has a near centurylong history, including over 60 years of industrial production of heat and power, and the respective management of ash deposits. In the current paper, the results of the last decade's studies on the processes taking place in Estonian OS ash fields have been analysed. The complex composition of ash and its transformation reactions under ambient conditions have been considered. It is shown that the hydraulic ash removal and wet depositing system works as a natural $\mathrm{CO}_{2}$ trap. The algorithm for the calculation of the resulting effect has been evaluated.
\end{abstract}

Keywords: oil shale ash, deposition, environmental impact.

\section{Introduction}

Solid fossil fuels, e.g. coal, comprise the third largest resource of the world's total primary energy supply. The rising demand for energy, especially in the fast-growing economies of Asia, Africa and the Middle-East, will increase the overall solid fuel consumption in the coming decades [1,2]. This forces

\footnotetext{
* Corresponding author: e-mail mai.uibu@ttu.ee
} 
one to use lower-quality fossil fuels like oil shale (OS), whose total worldwide resources as extractable shale oil are at least 500 billion tons. A serious shortcoming of the usage of OS-type low-quality fuels is the large amount (40-85\% of the fuel) of ash remaining after shale processing by either combustion or retorting [3]. This is nearly an order of magnitude greater than for typical coal fuels. Moreover, many types of OS are rich in carbonate mineral phases, meaning that besides $\mathrm{CO}_{2}$ emissions from burning organic matter, significant quantities of this gas are additionally released due to the partial or complete thermal dissociation of carbonate phases. However, according to both laboratory and industrial-scale studies $[4,5]$ this high content of carbonate minerals makes OS (also in mixtures with coal) advantageous for $\mathrm{SO}_{2}$ binding in circulating fluidized-bed combustion (CFBC) boilers without the need to add $\mathrm{CaO}$ or limestone to control sulphur emission [6, 7].

The Estonian kukersite OS is the largest industrially exploitable OS resource in the world [8]. In Estonia, it is the most important natural resource and is of vital importance to the country's energy sector. About two thirds of Estonia's fuel balance is covered by OS, and its share in electricity production exceeds $95 \%[9,10]$. In the past five years, the annual OS mining output has been 14 to $16 \mathrm{Mt}$ and is estimated to slowly increase $[10,11]$. The majority (about $80 \%$ ) of the OS mined is utilised in thermal power plants, for electricity and heat production. About $20 \%$ is used for shale oil and shale gas retorting, and the rest is mostly used in the cement industry. The combustion of OS in electric power plants and retorting in the oil shale chemical industry for the production of shale oil and combustible gas is accompanied by the generation of huge amounts of wastes - OS ash and semi-coke. In electric power plants, the amount of ash that remains after combustion is $45-48 \%$ of OS dry mass [12]. The formation of such a large amount of ash creates difficulties in the heat-transfer and phase-separation processes in boilers, as well as in the transport and deposition of ash. Only a small percentage of ash finds its way to secondary use, either in the building materials industry, in agriculture for liming acid soils or in road construction as a stabilising agent of roadbeds. Despite extensive research on its reusability options, the vast majority of ash is still deposited in ash fields next to the power plants (Fig. 1). The amount of the deposited ash ranges between 5 and $7 \mathrm{Mt}$ each year, and the total volume of waste ash is close to $300 \mathrm{Mt}[13]$.

Kukersite OS is highly calcareous, the content of calcite and dolomite in OS mineral matter varying between 20 and $70 \%$. The ash remaining after combustion is, due to the partial-to-complete thermal decomposition of carbonate minerals and subsequent reactions with sulphur containing flue gases, rich in free lime $(\mathrm{CaO})$ and anhydrite $\left(\mathrm{CaSO}_{4}\right)$. As a result, the recycled ash transportation water $\left(15-20 \mathrm{~m}^{3}\right.$ per ton of ash deposited) and the water draining off the ash and semi-coke deposits are highly alkaline (pH 12-13). 


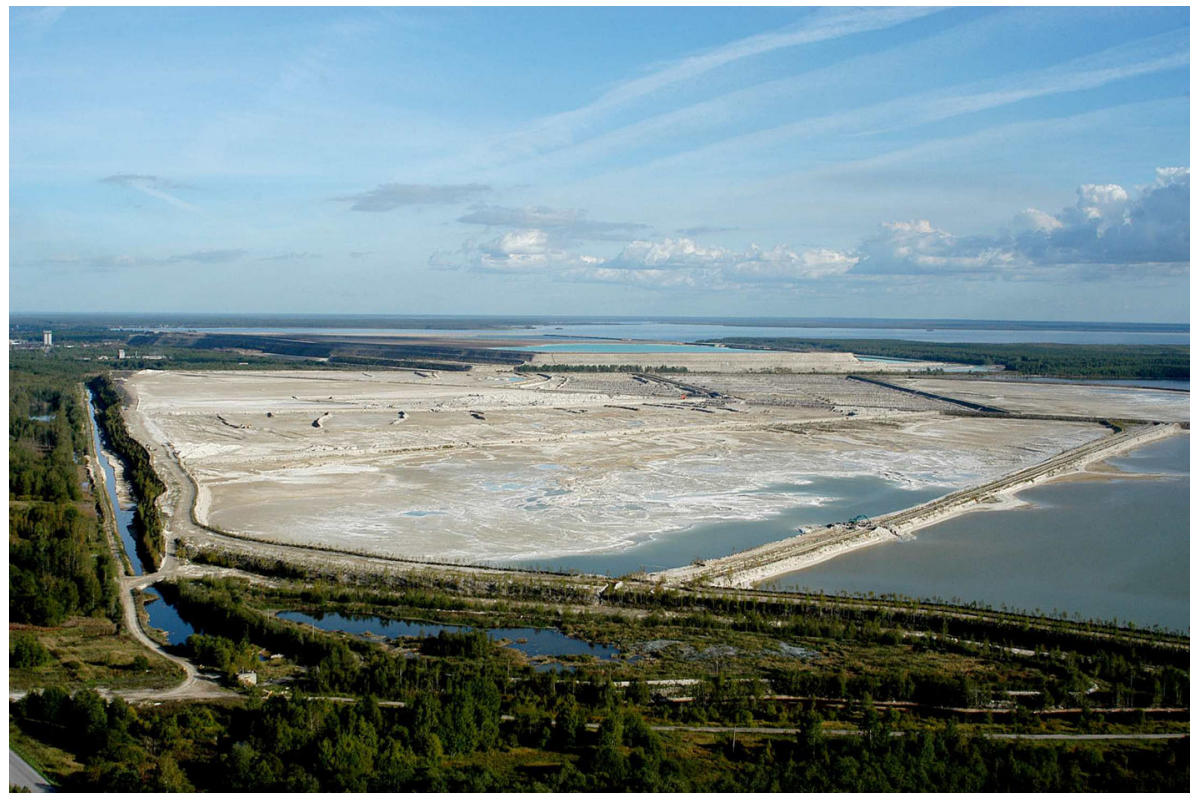

Fig. 1. Oil shale ash deposits in northeastern Estonia.

The geology of OS as well as its combustion and retorting technologies have been studied over the past few decades in detail by many researchers $[3,11,14-25]$. However, less attention has been devoted to the phase composition and diagenesis of the solid wastes remaining after OS combustion or retorting. Recent trends in environmental policies and concerns have forced an emphasis to be placed on the study of these solid wastes in order to determine factors that may influence the surrounding environment. In respect of this, significant advances have been made in recent years in the studies of $\mathrm{CO}_{2}$ capture by OS ash [4, 26-28].

The objective of the current paper was to compile relevant data about:

- Estonian kukersite-type OS: occurrence, geology, and industrial use for heat and power production;

- characterisation of OS ash formed by different combustion technologies: chemical and phase composition as well as physical characteristics;

- environmental problems related to the open-air deposition of OS ash;

- diagenetic transformations in open-air ash deposits: results of model experiments with fresh ash versus the composition of natural samples collected from drill cores from a vertical cross section of the deposit;

- natural $\mathrm{CO}_{2}$ binding by the ash sediment and scenarios for process acceleration;

- reclamation and utilisation of ash deposits. 


\section{Kukersite OS geology and composition}

OS is a fine-grained sedimentary rock that contains relatively large amounts (10-65\%) of organic matter (kerogen) from which shale oil and combustible gas can be extracted by destructive distillation. OS is found worldwide in all types of marine, lacustrine or terrestrial sedimentary rocks of the Cambrian to Neogene age. The organic-rich calcareous sediment - kukersite - found in sediments of the Lower to Upper Ordovician time in Estonia and northwestern Russia is a marine OS [12]. The organic matter of kukersite is composed mainly of kerogen, with a few percent of bitumen [17]. Kerogen consists almost entirely of discrete organic bodies (telalginite) derived from a colonial algal microorganism Gloeocapsomorphaprisca $[17,29]$. However, Kattai et al. [11] point out that kukersite kerogen, although deposited in a normal marine environment, is more similar to lacustrine OS and sapropelic coals than to the kerogen of a typical marine OS.

Kukersite occurs in an area of about $5000 \mathrm{~km}^{2}$ in northeastern Estonia (the Estonian deposit) and northern Estonia (the Tapa deposit), as well as in northwestern Russia (the Leningrad deposit) (Fig. 2). In the Estonian deposit, the productive seam thickness varies from 2.7 to $3.0 \mathrm{~m}$ in the northern part of the deposit where it outcrops on the surface, to $1.4-2.0 \mathrm{~m}$ in the southern and western parts where the seam is buried at a depth of 50-90 m. In the Tapa deposit, the OS seam depth is $60-170 \mathrm{~m}$ below ground. The OS seam has a maximum thickness of $2.0-2.3 \mathrm{~m}$ in the central part of the deposit. The Tapa deposit is a passive/prospective resource and so far has not been used [11]. The reserves of the Estonian deposit lying in an area of about $2973 \mathrm{~km}^{2}$ amount to nearly $5 \cdot 10^{9} \mathrm{t}$, including $1.5 \cdot 10^{9} \mathrm{t}$ of active reserves [3]. The Estonian kukersite deposit holds the largest OS resource in the world that is used industrially today [12]. OS has been known in Estonia since the

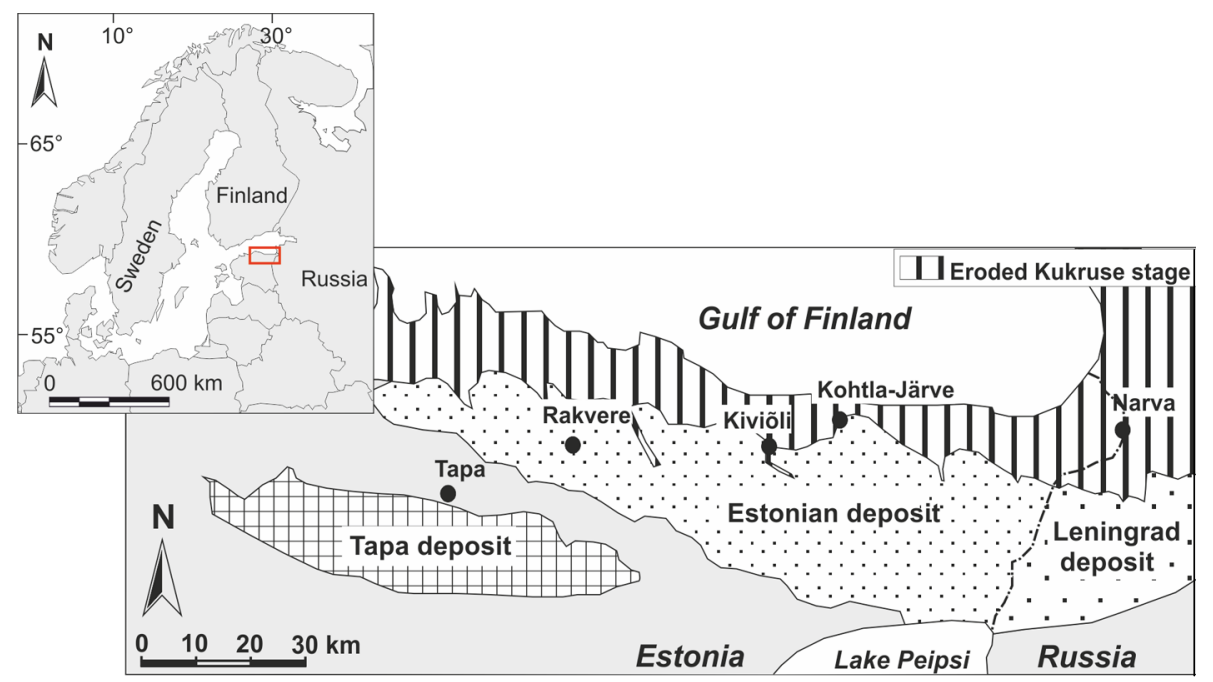

Fig. 2. Oil shale deposits in northeastern Estonia. 
$18^{\text {th }}$ century, and the large-scale exploration of its deposits and subsequent exploitation already started during World War I.

The major components of the OS organic matrix are phenolic moieties with linear alkyl side-chains $[20,30,31]$. The elemental composition of OS organic matter is characterised by low $\mathrm{C} / \mathrm{H}$ and $\mathrm{C} / \mathrm{O}$ ratios, which is common in liquid fuels. The average $\mathrm{C}$ value in OS organic matter is $77.5 \%, \mathrm{O} 10 \%$, $\mathrm{H} 9.7 \%$ and $\mathrm{S} 1.8 \%$. The high chlorine content $(0.75 \%)$ is another notable characteristic. The total moisture of OS burned at power plants is $11-13 \%$, and its calorific value is $8-10 \mathrm{MJ} / \mathrm{kg}$, which is lower than that of other fuels (as, for example, the average of coal $22.5 \mathrm{MJ} / \mathrm{kg}$, natural gas $33.5 \mathrm{MJ} / \mathrm{m}^{3}$, and peat $16.5 \mathrm{MJ} / \mathrm{kg}$ ) $[3,25]$.

Along with organic matter, Estonian kukersite contains significant amounts of carbonaceous and terrigenous matter. The mineral part of OS can be divided into two large groups: a terrigenous or sandy-clay part and a carbonate part. The terrigenous part is closely intertwined with OS organic matter and can thus be regarded as an inherent mineral impurity. The carbonate matter, in contrast, usually forms separate layers or is arranged as concretions inside and between OS seams, and is therefore considered an extraneous mineral matter [3]. The chemical and mineral compositions of the carbonate and terrigenous parts of OS are quite stable, irrespective of the areal location of the deposit or the layer. However, the ratio of the terrigenous to carbonate part may vary considerably and is reflected in the fuel's quality. The mineral part of OS is dominated by carbonate minerals (20-70\%), including appreciable calcite and less dolomite. The share of the terrigenous fraction is about $15-60 \%$, and the proportion of organic matter varies between 10 and $60 \%[3,12]$.

The carbonate part of OS (Table 1) is explicitly dominated by $\mathrm{CaO}$ (48.1\%), followed by $\mathrm{MgO}(6.6 \%)$ [32]. The terrigenous part of the OS mineral matter is predominated by $\mathrm{SiO}_{2}, \mathrm{Al}_{2} \mathrm{O}_{3}, \mathrm{Fe}_{2} \mathrm{O}_{3}$ and $\mathrm{K}_{2} \mathrm{O}$. It contains a small percentage of crystal water bound to clay mineral phases. As suggested by its chemical composition, the main minerals in the carbonate part are calcite $(30-70 \%)$ and dolomite (5-30\%). A negligible amount of siderite $(0.3 \%)$ has also been detected. The terrigenous part of OS is characterised as a mixture of mainly quartz $(\sim 11 \%)$, clay mineral illite $(\sim 15 \%)$ and feldspars

Table 1. Chemical composition of oil shale mineral matter, wt\% [32]

\begin{tabular}{|l|r|l|r|}
\hline \multicolumn{2}{|c|}{ Terrigenous part, wt $\%$} & \multicolumn{2}{|c|}{ Carbonate part, $\mathrm{wt} \%$} \\
\hline $\mathrm{SiO}_{2}$ & 59.8 & $\mathrm{CaO}$ & 48.1 \\
$\mathrm{CaO}$ & 0.7 & $\mathrm{MgO}$ & 6.6 \\
$\mathrm{Al}_{2} \mathrm{O}_{3}$ & 16.1 & $\mathrm{FeO}$ & 0.2 \\
$\mathrm{Fe}_{2} \mathrm{O}_{3}$ & 2.8 & $\mathrm{CO}_{2}$ & 45.1 \\
$\mathrm{TiO}_{2}$ & 0.7 & & \\
$\mathrm{MgO}$ & 0.4 & & \\
$\mathrm{Na}_{2} \mathrm{O}$ & 0.8 & & \\
$\mathrm{~K}_{2} \mathrm{O}$ & 6.3 & & \\
$\mathrm{FeS}_{2}$ & 9.3 & & \\
$\mathrm{SO}_{3}$ & 0.5 & & \\
$\mathrm{H}_{2} \mathrm{O}$ & 2.6 & & \\
\hline
\end{tabular}


(mainly orthoclase) (5\%). Iron is present in the OS mineral matter mainly as marcasite/pyrite, 4-7\% (Table 2). Microelement concentrations in OS usually do not exceed their respective average concentrations in the earth's crust (Table 3). The concentrations of $\mathrm{Sr}, \mathrm{Br}$ and $\mathrm{Ba}$ are somewhat higher, but in most cases OS is not enriched with trace elements [3,11].

Table 2. Mineral composition of oil shale, wt\% [39]. The variation range of mineral composition is shown according to Vingisaar et al. [16]

\begin{tabular}{|l|l|c|r|r|c|}
\hline \multicolumn{2}{|c|}{ Sample/Mineral } & Kiviõli 1 & Kiviõli 2 & Viru & Content range \\
\hline Quartz & $\mathrm{SiO}_{2}$ & 12.6 & 7.8 & 12.7 & $4-18$ \\
Calcite & $\mathrm{CaCO}_{3}$ & 36.0 & 60.4 & 33.8 & $30-70$ \\
Dolomite & $\mathrm{CaMg}_{\left(\mathrm{CO}_{3}\right)_{2}}$ & 14.7 & 7.8 & 17.7 & $5-30$ \\
K-feldspar & $\mathrm{KAlSi}_{3} \mathrm{O}_{8}$ & 9.1 & 3.5 & 9.4 & $1-2$ \\
Albite & $\mathrm{NaAlSi}_{3} \mathrm{O}_{8}$ & & tr. & & n.d. \\
Chlorite & $\mathrm{Al}_{2} \mathrm{Mg}_{5} \mathrm{Si}_{3} \mathrm{O}_{10}(\mathrm{OH})_{8}$ & 5.8 & 2.1 & 3.3 & $0-3$ \\
Illite & $\mathrm{KAl}_{2}\left(\mathrm{Si}_{3} \mathrm{AlO}_{10}\right)(\mathrm{OH})_{2}$ & 14.6 & 11.1 & 19.0 & $5-36$ \\
Pyrite & $\mathrm{FeS}_{2}$ & 6.1 & 6.9 & 4.1 & n.d. \\
Gypsum & $\mathrm{CaSO}_{4} \cdot 2 \mathrm{H}_{2} \mathrm{O}$ & 1 & tr. & & n.d. \\
\hline
\end{tabular}

n.d. not determined

tr. - trace amount

Table 3. Proportions of selected trace elements in oil shale and the earth's crust, ppm [3,11]

\begin{tabular}{|l|c|c|c|}
\hline \multicolumn{1}{|c|}{ Element } & Symbol & Oil shale & Earth's crust \\
\hline Antimony & $\mathrm{Sb}$ & $0.5-0.6$ & 0.4 \\
Arsenic & $\mathrm{As}$ & $7.6-21$ & 50 \\
Barium & $\mathrm{Ba}$ & $1,150-1,500$ & 650 \\
Mercury & $\mathrm{Hg}$ & $0.08-0.3$ & 0.08 \\
Cadmium & $\mathrm{Cd}$ & $0.4-4$ & 0.5 \\
Cobalt & $\mathrm{Co}$ & $2.9-3$ & 20 \\
Chromium & $\mathrm{Cr}$ & $17-38$ & 83 \\
Manganese & $\mathrm{Mn}$ & $310-387$ & 950 \\
Molybdenum & $\mathrm{Mo}$ & 3 & 1.5 \\
\hline Nickel & $\mathrm{Ni}$ & $12-21$ & 60 \\
Lead & $\mathrm{Pb}$ & $20-30$ & 16 \\
Thorium & $\mathrm{Th}$ & $2.3-3.4$ & 13 \\
Caesium & $\mathrm{Cs}$ & $1.7-2.3$ & 3.5 \\
Uranium & $\mathrm{U}$ & 3 & 2.8 \\
Copper & $\mathrm{Cu}$ & $17-55$ & 47 \\
Scandium & $\mathrm{Sc}$ & 4.2 & \\
Vanadium & $\mathrm{V}$ & 28 & \\
Zinc & $\mathrm{Zn}$ & 48.7 & \\
\hline Gallium & $\mathrm{Ga}$ & 8 & \\
Selene & $\mathrm{Se}$ & $<0.1$ & \\
Bromium & $\mathrm{Br}$ & 100 & \\
Rubidium & $\mathrm{Rb}$ & 39 & \\
Yttrium & $\mathrm{Y}$ & 5.4 & \\
Zircon & $\mathrm{Zr}$ & 49 & \\
Niobium & $\mathrm{Nb}$ & 4.5 & \\
Hafnium & $\mathrm{Hf}$ & 1.8 & \\
Tungsten & $\mathrm{W}$ & 0.6 & \\
\hline
\end{tabular}




\section{Industrial use of kukersite OS for heat and power production}

\subsection{Combustion technologies applied}

Since the beginning of the continuous commercial mining of OS in 1920, about 1 billion tons of OS has been mined. The peak annual production (mining) of kukersite was 31 million tons in 1980. The mining of OS has decreased since then, declining to 21.1 million tons in 1990 and 12.5 million tons in 1998. In recent years, mining has somewhat stabilised at $14-16 \mathrm{Mt}$ $[10,11]$.

The main industrial activities that employ the OS resource are electricity and heat generation and conversion to other forms of fuel (shale oil, shale oil gas) [33]. Before and during the early years after WW II electricity production was a side-branch in OS consumption, as preference was given to its processing into oil products and gas fuel. Today in Estonia, OS is primarily used for the production of electricity at two large power plants (PPs) - the Baltic Power Plant (established in 1959) and the Estonian Power Plant (established in 1969) based on pulverised firing (PF) and circulating fluidized-bed combustion (CFBC) technologies [3]. In addition, three smallscale local PPs are exploiting OS. The pulverized firing technology (Fig. 3) employs pulverized OS (median size $45-55 \mu \mathrm{m}$ ) that is fed to the combustion chamber using hot air as the transporting medium and is then mixed with hot secondary air. During combustion, heat is released and transferred through heat transfer surfaces to water (steam). At the same time, the fuel mineral matter undergoes various conversion processes, and ash formation takes place. The combustion temperature inside the $\mathrm{PF}$ furnace is about $1350-1400{ }^{\circ} \mathrm{C}$ and may reach $1500{ }^{\circ} \mathrm{C}$.

In 2004, two old PF boilers, one at the Baltic Power Plant and one at the Estonian Power Plant, were replaced with new CFBC boilers (Fig. 3), with a maximal power output of $215 \mathrm{MW}$. In the more effective and environmentally friendly CFBC boiler, the superficial flue gas velocity exceeds gravitational force; the particles leave the bed and are transported by the rising flue gas to the separator where most of the particles are captured and returned to the bed, and a continuous circulation of the solid phase takes place.

CFBC is a low-temperature combustion technology where temperatures are in the range of 750 to $950{ }^{\circ} \mathrm{C}$. High temperatures are not needed if the fuel is fed to the furnace where the temperature in the combustion bed is equal to or slightly higher than the fuel ignition temperature that supports continuous combustion. The lower combustion temperature, as compared to $\mathrm{PF}$ combustion, favours $\mathrm{SO}_{2}$ capture, which is almost complete. At lower combustion temperatures, free $\mathrm{CaO}$ reacts more readily with $\mathrm{SO}_{2}$ forming a solid $\mathrm{CaSO}_{4}$ (anhydrite) phase.

The Development Plan of the Estonian Electricity Sector [34] states that by 2018 the PF technology based boilers will be partly shut down, partly replaced with $\mathrm{CFBC}$ boilers, and four PF power units will be fitted with 


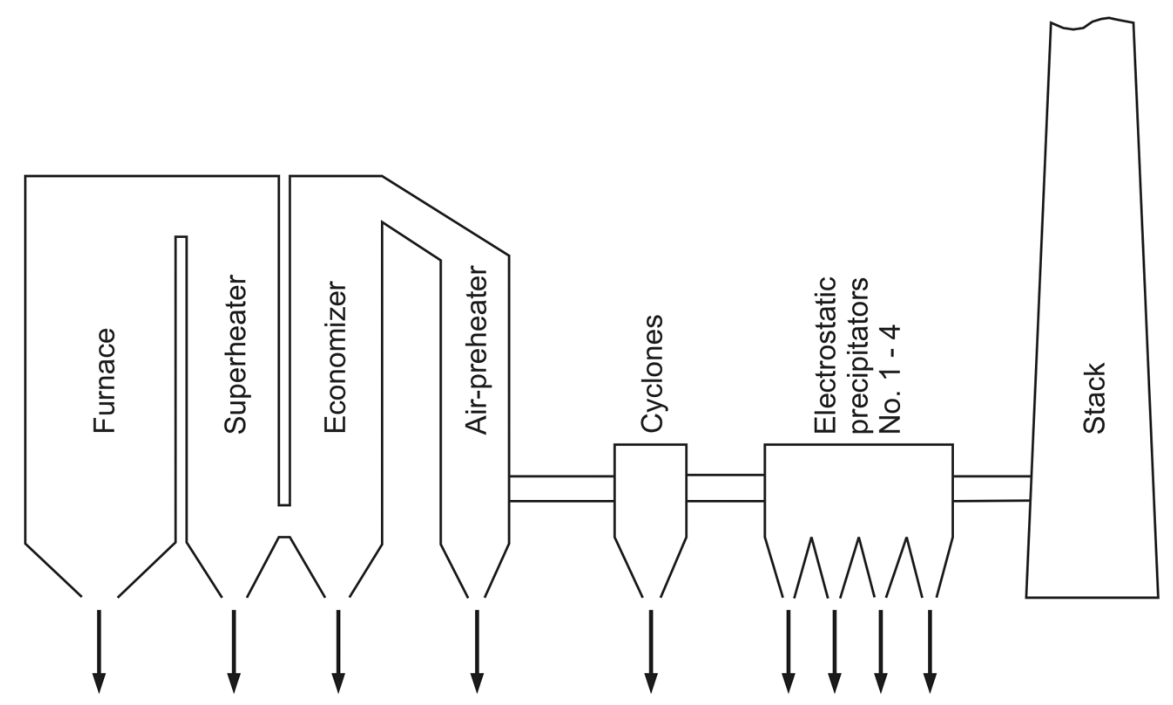

PF boiler scheme

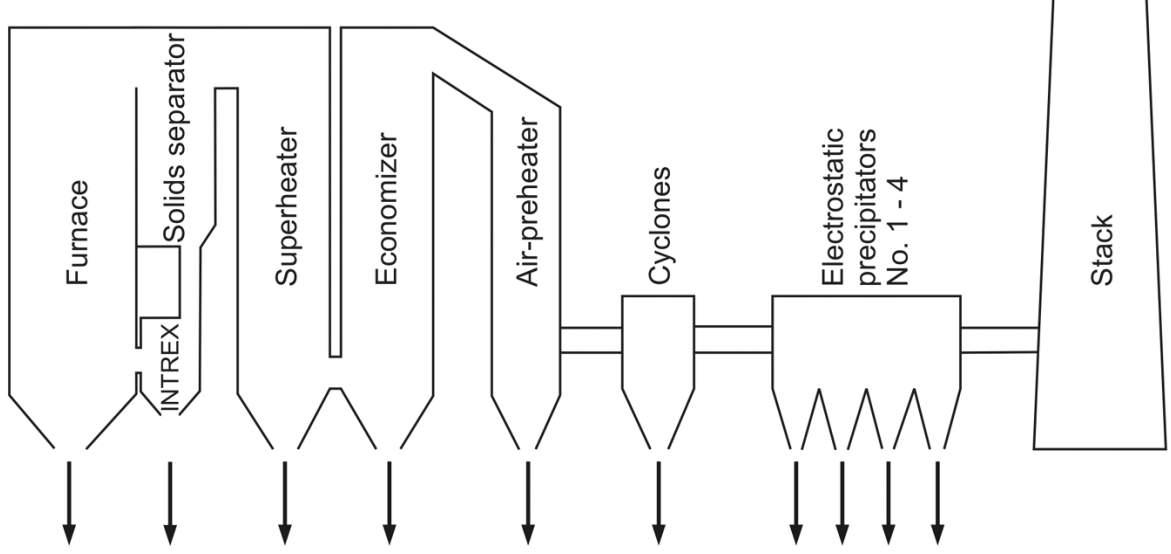

CFBC boiler scheme

Fig. 3. Ash removal points along the boiler gas pass.

sulphur and nitrogen (oxides) capture systems. This should result in higher boiler efficiency and a substantial saving in fuel [35] in CFBC boilers, as well as a significant reduction in air pollution [36] due to the use of renovated power generation units. 


\subsection{Comparative characterisation of $\mathrm{OS}$ ash formed in PF and CFBC boilers}

The different combustion conditions present in PF and CFBC technologies cause remarkable differences in phase and chemical composition between ash fractions [37, 38]. Specifically, the sharp difference in the operating temperature and fuel particle size [3] results in the different behaviour of Ca-containing compounds (Figs. 4, 5) [37].

Kuusik et al. [37] and Bitjukova et al. [39] showed that all ash types are dominated by the presence of $\mathrm{CaO}$ (total) whose proportion varies from 26 to $55 \%$ in the $\mathrm{PF}$ ash and from 26 to $49 \%$ in the CFBC ash. The proportion of $\mathrm{CaO}$ along the boiler gas pass decreases both in PF and CFBC boiler ashes, from $49 \%$ in the bottom ash to $30 \%$ in the last fields of the electro-
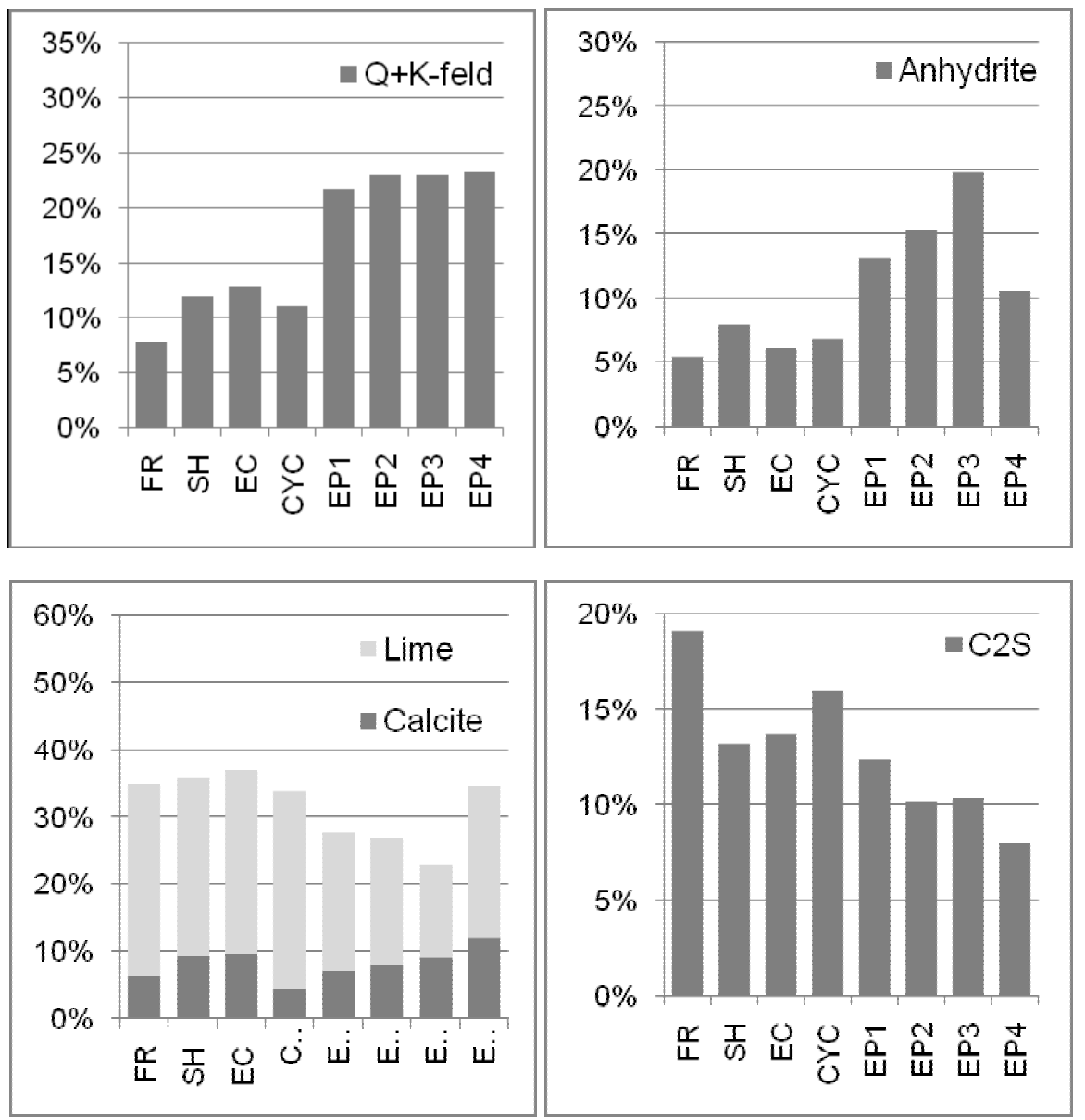

Fig. 4. Distribution of the main components in PF ash (FR - furnace ash; $\mathrm{SH}-$ superheater ash; EC - economiser ash; CYC - cyclone ash; EP - electrostatic precipitator ash, fields $1-3$ ). 

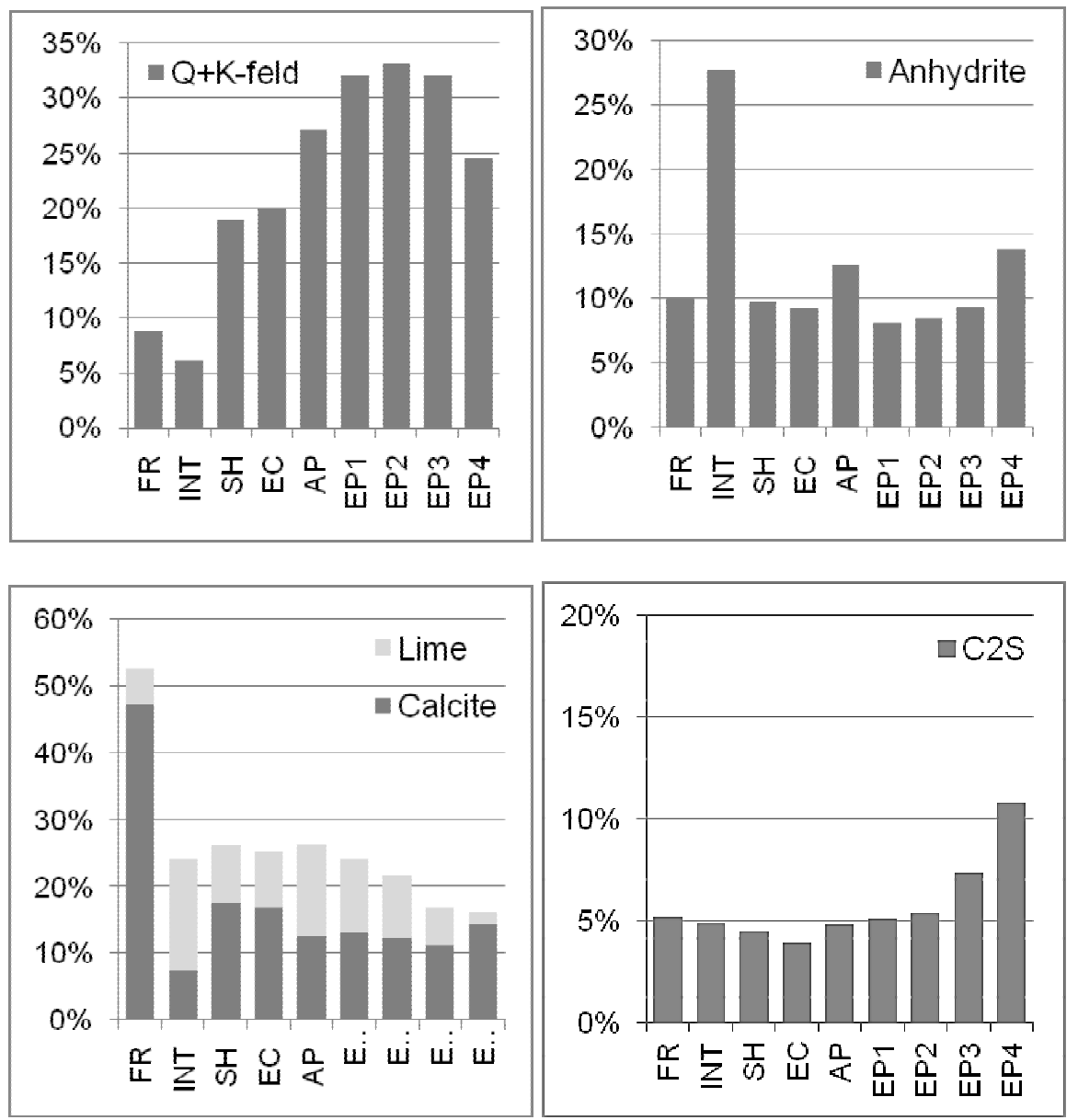

Fig. 5. Distribution of the main components in CFBC ash (FR - furnace ash; INT INTREX ash; SH - superheater ash; EC - economiser ash; AP - air preheater ash; EP - electrostatic precipitator ash, fields 1-4).

static precipitators (average values). There is a large variation in the proportion of $\mathrm{MgO}(2-15 \%) . \mathrm{MgO}$ is mostly derived from the thermal decomposition of dolomite $\left(\mathrm{CaMg}\left(\mathrm{CO}_{3}\right)_{2}\right)$ and this variability is evidently due to the variation in dolomite admixture in raw OS, depending on the geological section used for mining. The separation of $\mathrm{S}$ along the boiler gas pass in $\mathrm{PF}$ ashes shows a gradual enrichment in finer ash fractions, whereas in CFBC boilers, as expected, the $\mathrm{S}$ proportion is the highest in the ash removed in the INTREX preheater [37, 39].

Variations in the mineral composition of ash fractions are related to those in lime (free $\mathrm{CaO}$ ), the proportion of which varies from about $1.6 \%$ in the CFBC ash to a maximum of $24.6 \%$ in the PF ash. In concordance with the chemical composition of samples, the proportion of lime in PF ash types at both power stations shows a gradual decrease from the bottom ash to the 
electrostatic precipitator ash (Fig. 4). In CFBC ash types, however, the distribution of free $\mathrm{CaO}$ is more complex (Fig. 5). The proportion of lime in the furnace ash is low compared to the ash from PF boilers; it reaches maximum proportions in the economizer-air preheater zone, and then decreases again through the fields of electrostatic precipitators. This variation is evidently determined by different processes taking place in different devices of the boiler complex: the most active binding of $\mathrm{CO}_{2}$ takes place in the upper part of the combustion chamber along with attrition of particles, resulting in the formation of finer fractions which are leaving the chamber with the gas flow and are later separated from the flue gas by electrostatic precipitators. In contrast with lime, the proportion of anhydrite $\left(\mathrm{CaSO}_{4}\right)$ increases in PF boilers from about 5\% in the bottom ash to approximately 13 and $27 \%$ in the electrostatic precipitators at the Baltic Power Plant and the Estonian Power Plant, respectively. Also, if the proportions of Ca-silicate phases decrease along the boiler gas pass in PF boilers, then, in contrast, in the CFBC boiler system, the proportions of Ca-silicates are rather uniform in the first part of the ash removal system and increase nearly exponentially in the electrostatic precipitators (Figs. 4, 5).

In both cases, $\mathrm{Mg}$ was found to be mostly present as periclase $(\mathrm{MgO})$ and also partially bound as undecomposed carbonates (dolomite $\mathrm{CaMg}\left(\mathrm{CO}_{3}\right)_{2}$ can be found in the CFBC bottom ash) or silicates (merwinite, $\mathrm{Ca}_{3} \mathrm{Mg}\left(\mathrm{SiO}_{4}\right)_{2}$, melilite, $\left.(\mathrm{Ca}, \mathrm{Na})_{2}(\mathrm{Mg}, \mathrm{Al})(\mathrm{Si}, \mathrm{Al})_{3} \mathrm{O}_{7}\right)$. In the case of CFBC ashes, the silica compounds are chiefly present in residual fractions $\left(\mathrm{SiO}_{2}\right.$, $\left.\mathrm{KAlSi}_{3} \mathrm{O}_{8}, \mathrm{KAl}_{2}\left(\mathrm{Si}_{3} \mathrm{AlO}_{10}\right)(\mathrm{OH})_{2}\right)$, while the PF ash contains noticeably more secondary silicates $-\beta-\mathrm{Ca}_{2} \mathrm{SiO}_{4}, \mathrm{Ca}_{3} \mathrm{Mg}\left(\mathrm{SiO}_{4}\right)_{2}$, etc. The relatively higher content of secondary silicates can be explained by the significantly higher temperatures used in PF boilers, which leads to the formation of melted phases initiating reactions between free $\mathrm{CaO}$ and quartz or silicates. The content of sulphur (mainly in the form of anhydrite) is the highest in the INTREX ash of CFBC boilers. In the case of PF boilers, the sulphur content is higher in finer ash fractions [37, 39].

There is also a significant difference in the content of amorphous-glassy phases between PF and CFBC ashes. According to Mõtlep et al. [40], the content of glassy (X-ray amorphous) phases in $\mathrm{PF}$ ash fractions varies from about $27 \%$ in the furnace ash to a maximum of $38 \%$ in the cyclone ash, and decreases sequentially in the electrostatic precipitator system from $28 \%$ in the first field and $23 \%$ in the second field to only $1-2 \%$ in the last field of electrostatic precipitators. In the CFBC ash, however, the content of the amorphous phase is about $10-15 \%$, showing no significant variation between ash fractions [38].

The micromorphology of ash fractions [37, 39] shows that there are considerable differences between the ashes formed in PF and CFBC boilers (Fig. 6). The PF ash is, in most cases, characterised by a large portion of spherical glassy and/or hematite particles with a clump of aggregated particles. The relative proportion of spherical particles increases from the 
(a)

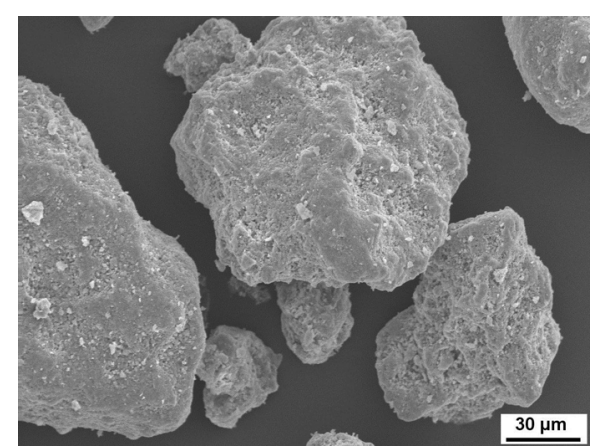

(c)

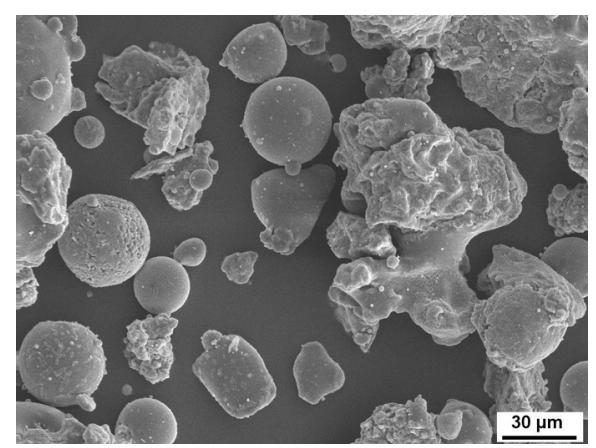

(b)

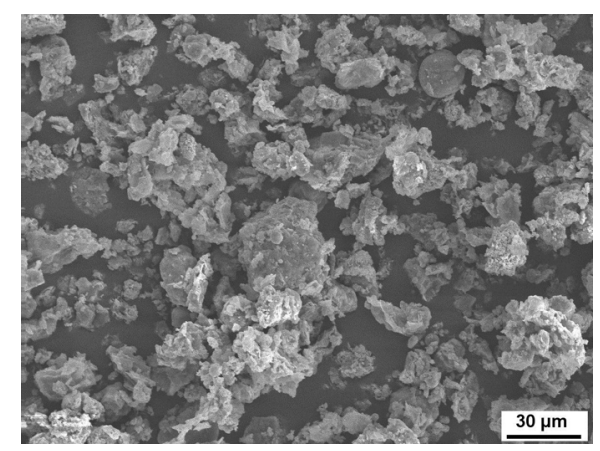

(d)

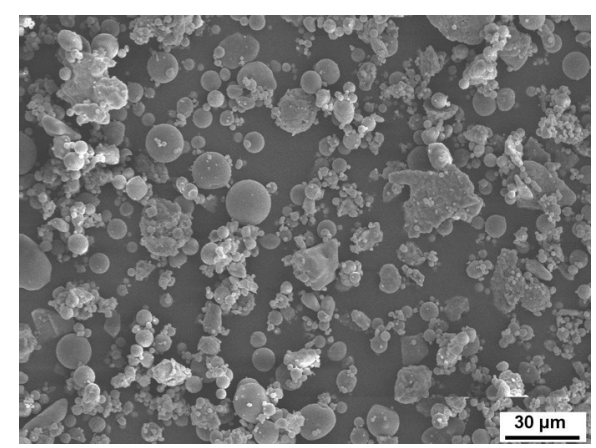

Fig. 6. A scanning electron microscopic image of CFBC INTREX ash (a); CFBC electrostatic precipitator ash (field 1) (b); PF cyclone ash (c); PF electrostatic precipitator ash (field 1) (d).

bottom ash to the ash fractions separated in the electrostatic precipitators. The CFBC ash particles formed at moderate temperatures are characterised by an irregular shape as well as by a porous and uneven surface, and only rarely have a spherical morphology.

Specific surface area (SSA) measurements showed the respective differences between CFBC and PF ashes to be tenfold [37]. While the SSA of the CFBC ash may reach $8.0 \mathrm{~m}^{2} / \mathrm{g}$, that of the $\mathrm{PF}$ ash is considerably lower, $0.3-0.8 \mathrm{~m}^{2} / \mathrm{g}$ on average. This is caused by the more intensive sintering of the PF ash at boiler temperatures. Thereby, the latter is expected to be more strongly influenced by the formation of reaction products on the surface of its particles, which could reduce mass transfer rates [41]. Thus, the reactivity of waste ashes towards $\mathrm{SO}_{2}$ and $\mathrm{CO}_{2}$ is determined by their chemical and phase composition, as well as by the physical structure of ash particles [41, 42].

The data presented above indicates that the compositional and physical variations in the PF and CFBC OS ashes are controlled by the firing technology, as well as by the grain size of OS used in both systems. The pulverized 
firing technology exploits high-temperature combustion where the nominal burning temperature inside the furnace chamber reaches $1350-1400{ }^{\circ} \mathrm{C}$, or $1500{ }^{\circ} \mathrm{C}$, whereas in the $\mathrm{CFBC}$ system the optimum temperature in the furnace chamber is about $800{ }^{\circ} \mathrm{C}$ [3]. The high temperature used in the PF technology ensures the major decomposition of carbonate mineral phases (dolomite, calcite) and melting of clay minerals that are a source for reactive silica as well as aluminium, which control the formation of secondary $\mathrm{Ca}$-silicate and $\mathrm{Ca}-\mathrm{Al}$-silicate phases. The firing temperature in CFBC boilers allows the complete thermal decomposition of dolomite, but only the partial decomposition of calcite and clay mineral phases. As a consequence, the $\mathrm{PF}$ ash is enriched with free $\mathrm{CaO}$ and secondary Ca-silicate phases, but the CFBC ash contains a higher share of residual mineral phases. A specific characteristic of the CFBC ash is its higher content of sulphur, which is mainly present in the form of anhydrite $\left(\mathrm{CaSO}_{4}\right)$ in the INTREX ash.

The grain size distribution of the OS fuel fired in PF and CFBC boilers differs considerably. The differences in phase composition may arise from the smaller median size of OS particles fed to PF boilers $(45-55 \mu \mathrm{m})$, whereas the median size of particles fed to CFBC boilers is $1-2 \mathrm{~mm}$, varying in the range of 0 to $10 \mathrm{~mm}$. This would explain the preservation of calcite and even dolomite in the unreacted cores of the furnace ash (bottom ash) particles, although the longer contact time of firing in the circulating fluidized bed should ensure a complete thermal dissociation of carbonate mineral phases even at lower temperatures.

The separation of the phases, both secondary and residual mineral, along the boiler gas pass depends on the size and phase composition of the respective particles that are different depending on firing technology as well as on gas velocities in the respective devices. The secondary Ca-silicates formed at high temperatures in PF boilers form large (partially intermelted) aggregates, which are concentrated in the coarse fractions of ash that are removed in the first zones of the ash removal system. In contrast, in CBFC boilers at lower firing temperatures the secondary Ca-silicate phases are concentrated in fine ash particles that are preferentially removed in electrostatic precipitators. In the PF ash, anhydrite is of finer grain size and mostly occurs in the ash particles separated in electrostatic precipitators. In CFBC boilers, anhydrite is mostly precipitated in the form of a shell on unreacted $\mathrm{CaO}$ cores [43, 44], thus forming relatively large particles. As a result, anhydrite is mostly found in the first part of the boiler gas pass (in the INTREX ash) and, to a somewhat lesser degree, in adjacent zones (Figs. 4, 5) [37, 39].

\subsection{Deposition of OS ash}

The industrial use of low-calorific OS generates large volumes of mineral waste - ash. Producing $1 \mathrm{MWh}$ of OS electricity is associated with ca 0.5 ton of waste ash that has to be properly treated and stored. More than $95 \%$ of the ash formed by OS combustion (approximately 6-7 Mt annually) is trans- 
ported to ash fields and remains there for indefinite periods (Table 4). The long-term operating experience shows that the hydraulic transport and openair deposition of OS ash have proven to be the most viable handling methods in both economic and technical terms. At the same time, several environmental concerns accompany this method, and these are no easy tasks to solve. Today, almost $300 \mathrm{Mt}$ of OS ashes is disposed of in such deposits.

Table 4. Basic information about oil shale ash transportation systems

\begin{tabular}{|c|c|c|c|}
\hline Information & $\begin{array}{l}\text { Baltic PP ash } \\
\text { field no } 1\end{array}$ & $\begin{array}{l}\text { Baltic PP ash } \\
\text { field no } 2\end{array}$ & $\begin{array}{l}\text { Estonian PP } \\
\text { ash field }\end{array}$ \\
\hline Total ash field area, $10^{3} \mathrm{~m}^{2}$ & 4900 & 5700 & 8100 \\
\hline $\begin{array}{l}\text { Upper ash field area (incl. actual } \\
\text { disposal area), } 10^{3} \mathrm{~m}^{2}\end{array}$ & $3600(1780)$ & 4000 & $5000(4300)$ \\
\hline $\begin{array}{l}\text { Lower buffer basin area (incl. basin } \\
\text { area), } 10^{3} \mathrm{~m}^{2}\end{array}$ & $100(900)$ & 1700 & $3100(2900)$ \\
\hline Circulating water volume, $10^{3} \mathrm{~m}^{3}$ & 4298 & & 7166 \\
\hline Deposited ash volume, $10^{6} \mathrm{t}$ & 91,9 & 31,9 & 153 \\
\hline
\end{tabular}

The OS ash handling system consists of three processes: (1) transportation of ash, (2) disposing of ash in ash fields, and (3) recirculation of the settled transportation water [38]. The transportation process includes the mixing of the ash collected from different points of the boiler gas pass with water at an ash-to-water ratio of 1:20. The ash pulp formed is pumped via pipelines to the ash depositing area (ash fields). It has to be emphasised that water plays several important roles in the process. Firstly, water is the primary transportation media in the system. Secondly, it acts as a coolant to reduce the ash temperature, which is higher than $700{ }^{\circ} \mathrm{C}$ at the beginning of the ash removal cycle. Thirdly, water serves as the reaction media for the hydration of $\mathrm{CaO}$ and dissolution of $\mathrm{CO}_{2}$ from the atmosphere. More than 5 million $\mathrm{m}^{3}$ of transportation water circulates in the ash removal system at both large power plants in Estonia.

Ash pulp is pumped to the settling ponds where the solid particles are deposited gravitationally due to the lowering of the flow rate. Over time, the settled ash becomes solidified and ash stone is formed. Water as a carrier is directed to lower settling/buffer ponds. The stored material (ash stone) can be considered a stable solid material according to EU regulations for landfill (Council Directive 1999/31/EC) [45].

After the settling phase, the transportation water is collected from the lower settling/buffer ponds where the settling of the finest part of OS ash (less than $0.6 \%$ of the total ash stored) takes place. At the same time, up to $3 \%$ of the power plant $\mathrm{CO}_{2}$ emissions become bound into a stable mineral form via chemical reactions between atmospheric $\mathrm{CO}_{2}$ and alkaline transportation water and hydrated ash particles (see 4.1). The settled water is directed back to the ash removal system via open channels. 
The hardened material (ash stone) forms a stable deposit body with suitable infiltration properties to fulfil the EU Landfill criteria (Council Directive 1999/31/EC) [45]. As the majority of ash fields are covered with water, dusting is kept minimal even during longer operation periods. The main environmental impacts and risks are connected with the large volumes of alkaline transportation water. The ash transportation water is designed to circulate in the closed system. The volume of water that circulates in the system is influenced by the balance of precipitation/evaporation, as well as by its chemical binding by ash. Generally, some water has to be added to the system to guarantee its stable functioning. Efforts have been made by Eesti Energia to avoid possible leakages or infiltration of the transportation water into the surrounding environment.

\section{Ageing behaviour of OS ash under open-air conditions}

\subsection{Chemical changes in ash under model conditions}

The ageing behaviour of OS ash under various model conditions has been the subject of a number of studies [27, 46-48]. The characterization of the ash types studied and depositing conditions are summarised in Table 5. The

Table 5. Conditions for natural carbonation of oil shale ash and formation of ash stone

\begin{tabular}{|c|c|c|c|c|c|c|c|c|}
\hline Ash & $\begin{array}{c}\mathrm{CaO}_{\mathrm{f}}, \\
\%\end{array}$ & $\begin{array}{c}\mathrm{CO}_{2}, \\
\%\end{array}$ & $\begin{array}{c}\mathrm{S}: \mathrm{L}, \\
\mathrm{kg} / \mathrm{kg}\end{array}$ & $\begin{array}{l}\mathrm{h}, \\
\mathrm{cm}\end{array}$ & Conditions & $\begin{array}{l}\text { Time } \\
\text { period }\end{array}$ & Analysis & Ref. \\
\hline \multicolumn{9}{|c|}{ Hermetic conditions } \\
\hline PFA98 & 19.40 & 1.21 & $1: 0.6$ & - & hermetic & $3 d-12 w$ & XRD & {$[48]$} \\
\hline \multicolumn{9}{|c|}{ Open air conditions: $\mathrm{CO}_{2}$ binding } \\
\hline PFA97 & 29.0 & 0.39 & 0 & 0.1 & $18-20^{\circ} \mathrm{C}$, dry & \multirow[t]{2}{*}{$1-30 \mathrm{~d}$} & \multirow{2}{*}{$\begin{array}{l}\text { Chemical } \\
\text { analysis }\end{array}$} & \multirow[b]{2}{*}[46]{} \\
\hline PFA97 & 29.0 & 0.39 & $1: 0.3$ & 0.1 & $18-20^{\circ} \mathrm{C}$ & & & \\
\hline PFA98 & 19.40 & 1.21 & 1:0.6 & 0.5 & $\begin{array}{l}\text { mixed and } \\
\text { humidified daily }\end{array}$ & $1 \mathrm{~h}-12 \mathrm{w}$ & XRD & {$[48]$} \\
\hline PFA98 & 19.9 & 1.9 & $1: 0.3$ & $1-6$ & $\begin{array}{l}\text { summer/winter, } \\
\text { humidified (and } \\
\text { mixed) weekly }\end{array}$ & $1-11 \mathrm{w}$ & $\begin{array}{l}\text { Chemical } \\
\text { analysis }\end{array}$ & \begin{tabular}{|l|l}
{$[48]$} \\
\end{tabular} \\
\hline PFA04 & 20.46 & 0.9 & $1: 5$ & $1-6$ & \multirow{7}{*}{$\begin{array}{l}\text { summer/autumn/ } \\
\text { spring/winter, } \\
\text { humidified weekly } \\
(\mathrm{M}=15 \%)\end{array}$} & \multirow{7}{*}{$1-8 \mathrm{w}$} & \multirow{7}{*}{$\begin{array}{l}\text { Chemical } \\
\text { analysis }\end{array}$} & \multirow{7}{*}[27]{} \\
\hline PFA05 & 15.23 & 1.0 & $1: 5$ & $1-6$ & & & & \\
\hline PFA05 & 15.23 & 1.0 & $1: 0.3$ & $1-6$ & & & & \\
\hline CFBCA04 & 7.52 & 7.35 & $1: 5$ & $1-6$ & & & & \\
\hline CFBCA05 & 4.5 & 10.71 & $1: 5$ & $1-6$ & & & & \\
\hline CFBCA05 & 4.5 & 10.71 & 1:0.9 & $1-6$ & & & & \\
\hline $\begin{array}{l}\text { CFBCA04+ } \\
\text { PFA05 1:1 }\end{array}$ & 11.17 & 4.30 & $1: 5$ & $1-6$ & & & & \\
\hline \multicolumn{9}{|c|}{ Open air conditions: ash stone formation } \\
\hline PFA04 & 20.46 & 0.9 & $1: 5$ & 4 & \multirow{4}{*}{$\begin{array}{l}\text { summer }\left(20^{\circ} \mathrm{C}\right) \text {, } \\
\text { humidified weekly } \\
(\mathrm{M}=15 \%)\end{array}$} & \multirow{4}{*}{$1-16 \mathrm{w}$} & Com- & \multirow{4}{*}[27]{} \\
\hline PFA04 & 20.46 & 0.9 & 1:0.3 & 4 & & & pression & \\
\hline CFBCA04 & 7.52 & 7.35 & $1: 5$ & 4 & & & strength, & \\
\hline CFBCA04 & 7.52 & 7.35 & 1:0.9 & 4 & & & $\begin{array}{l}\text { water } \\
\text { absorption }\end{array}$ & \\
\hline
\end{tabular}


dry OS ash is relatively inactive towards $\mathrm{CO}_{2}$ at $20{ }^{\circ} \mathrm{C}$ and is slowly carbonated by $10-30 \%$ during one month of storage (Fig. 7) [46]. The hydrated ash stored in a thin layer $(0.1-0.5 \mathrm{~cm})$ is carbonated almost completely $(96.5 \%)$ by periodic moistening and mixing during the same storage period $[46,48]$. Changes in the content of lime $(\mathrm{CaO})$, quartz $\left(\mathrm{SiO}_{2}\right)$, anhydrite $\left(\mathrm{CaSO}_{4}\right)$, calcite $\left(\mathrm{CaCO}_{3}\right)$, belite $\left(\mathrm{Ca}_{2} \mathrm{SiO}_{4}\right)$, and portlandite $\left(\mathrm{Ca}(\mathrm{OH})_{2}\right)$ in the PF ash during 0.4-84 days of open-air hydration (Fig. 8) show that the main transformation processes in the hydrated ash take place quickly, in less than three days [48]. The slacking of lime (1) occurs during the first hours, although a certain amount of it remains unchanged even during a long-term hydration.

$$
\mathrm{CaO}+\mathrm{H}_{2} \mathrm{O} \rightarrow \mathrm{Ca}(\mathrm{OH})_{2}
$$

The amount of portlandite, the reaction product of lime and water, increases rapidly, and the binding of $\mathrm{CO}_{2}$ from the air with the formation of calcite occurs simultaneously (2). In four weeks, all of the $\mathrm{Ca}(\mathrm{OH})_{2}$ has reacted, and the rapid increase in the amount of calcite ceases.

$$
\mathrm{Ca}(\mathrm{OH})_{2}+\mathrm{CO}_{2} \rightarrow \mathrm{CaCO}_{3}+\mathrm{H}_{2} \mathrm{O}
$$

The further increase in calcite content can be explained by the reaction between the hydration products of secondary calcium silicates (3) and carbon dioxide from the air (2). During the long-term hydration, the amount of belite/larnite in the PF ash decreases, while that of calcite increases.

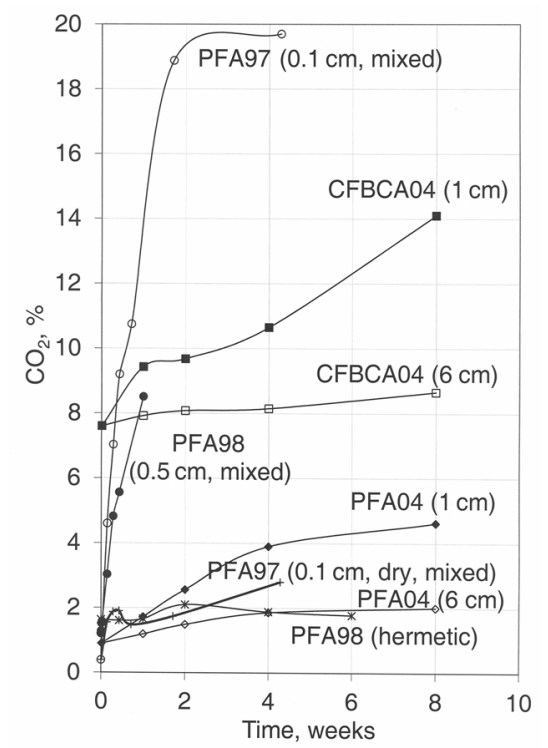

Fig. 7. Dynamics of $\mathrm{CO}_{2}$ content in ash sediment in open-air conditions $[27,46]$.

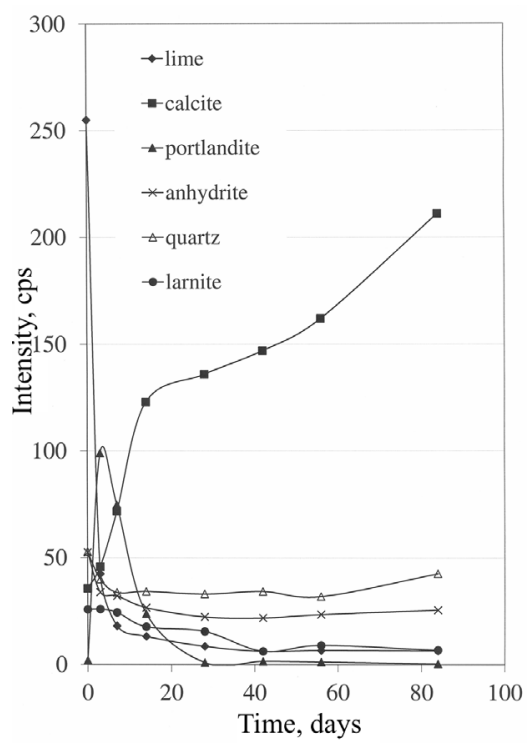

Fig. 8. Changes in the main mineral phases during 3-84 days of open-air hydration of a $0.5 \mathrm{~cm}$ PF ash layer [48]. 


$$
2 \mathrm{Ca}_{2} \mathrm{SiO}_{4}+4 \mathrm{H}_{2} \mathrm{O} \rightarrow 3 \mathrm{CaO} \cdot 2 \mathrm{SiO}_{2} \cdot 3 \mathrm{H}_{2} \mathrm{O}+\mathrm{Ca}(\mathrm{OH})_{2}
$$

The other important reactions of OS ash hydration involve anhydrite conversion to gypsum (4) and the formation of ettringite (5) and ferrites (e.g. $\left.\mathrm{Ca}_{12} \mathrm{Al}_{13.8} \mathrm{Fe}_{0.14} \mathrm{O}_{32}(\mathrm{OH})_{2}, \mathrm{Ca}_{2}(\mathrm{Al}, \mathrm{Fe})_{2} \mathrm{O}_{5}, \mathrm{CaAl}_{8} \mathrm{Fe}_{4} \mathrm{O}_{19}, \mathrm{CaO} \cdot 4 \mathrm{Al}_{2} \mathrm{O}_{3} \cdot 2 \mathrm{Fe}_{2} \mathrm{O}_{3}\right)$ $[40,46,48]$.

$$
\begin{gathered}
\mathrm{CaSO}_{4}+2 \mathrm{H}_{2} \mathrm{O} \rightarrow \mathrm{CaSO}_{4} \cdot 2 \mathrm{H}_{2} \mathrm{O} \\
3 \mathrm{Ca}(\mathrm{OH})_{2}+2 \mathrm{Al}(\mathrm{OH})_{3}+3 \mathrm{CaSO}_{4}+26 \mathrm{H}_{2} \mathrm{O} \rightarrow \mathrm{Ca}_{6} \mathrm{Al}_{2}\left(\mathrm{SO}_{4}\right)_{3}(\mathrm{OH})_{12} \cdot 26 \mathrm{H}_{2} \mathrm{O}
\end{gathered}
$$

In the $\mathrm{PF}$ ash, the transformation proceeds with the precipitation of hydrocalumite $\left(\mathrm{Ca}_{2} \mathrm{Al}(\mathrm{OH})_{7} \cdot 3 \mathrm{H}_{2} \mathrm{O}\right)$, which suggests that the ettringite formation is limited by the availability of dissolved sulphate, while the excess of aluminium is precipitated as Ca-aluminate(hydrate)-type phases.

Under hermetic conditions (single addition of water and subsequent airtight preservation), the hydration of PF ash principally follows the same path, except for the absence of carbonation reactions and the full transformation of lime into portlandite, the decrease in the content of quartz, the full disappearance of anhydrite and formation of other hydrate phases are somewhat hindered [48]. These conditions are presumably similar to those existing in the deeper layers of the ash field.

In case of PF ash a quick lime slacking at maximum rate takes place after 12-24 hours [48] and then the rate drops rapidly. In the experimental hydration of CFBC ash the reaction was completed in 72 hours, together with the dissolution of anhydrite and partial dissolution of periclase [49]. The slower hydration of this ash, as already noted by Anthony et al. [50], is most probably related to that $\mathrm{CFBC}$ ash solids are typically composed of an unreacted $\mathrm{CaO}$ core covered by a Ca-sulphate shell [43, 44]. Hydration starts with a slow water diffusion through the sulphate layer followed by a fast $\mathrm{CaO}$ hydration into portlandite. Similarly, the same mechanism is in place during the carbonation of hydrated particles in the CFBC ash, when the outer shell of anhydrite and/or gypsum retards the $\mathrm{CO}_{2}$ diffusion and slows the carbonation of CFBC ash, as noted by Kaljuvee et al. [51]. Additionally, $\mathrm{CO}_{2}$ transport is in this case probably further inhibited by $\mathrm{CaCO}_{3}$ formation in the outer perimeter of the hydrated portlandite particles, and the experimental carbonation in the CFBC ash took place during a much longer period, 58 days [49]. In contrast, in the PF ash portlandite was already carbonated during 28 days of the reaction [48]. Also, Liira et al. [49] report that in the CFBC ash, ettringite formation is accompanied by the precipitation of excess gypsum $\left(\mathrm{CaSO}_{4} \cdot 2 \mathrm{H}_{2} \mathrm{O}\right)$, which implies that aluminium, not sulphate as in the $\mathrm{PF}$ ash, is a limiting component in this type of ash, which is rich in anhydrite due to the effective $\mathrm{SO}_{2}$ immobilisation in the INTREX unit of CFBC boilers. 


\section{2. $\mathrm{CO}_{2}$ binding by $\mathrm{OS}$ ash and ash stone formation}

The dynamics and extent of seasonal $\mathrm{CO}_{2}$ binding by ash and the influence of different types of ashes and slurry preparation methods (Table 5) on the formation and properties of ash stone were studied on a laboratory scale by Uibu et al. [27] and Kuusik et al. [46]. It was shown that the most intensive $\mathrm{CO}_{2}$ binding takes place in the surface deposit layers within a few centimetres, while in the deeper layers the binding rate is moderate. The pile-up of fresh layers of ash suspension inhibits $\mathrm{CO}_{2}$ diffusion into the deeper layers and $\mathrm{CO}_{2}$ binding reactions. Summer weather conditions enhance the natural binding of $\mathrm{CO}_{2}$ into the surface layers of ash deposits, while the ambient temperature does not significantly influence the process in the deeper layers. Autumn/spring and winter weather conditions greatly reduce the rate and extent of the processes under discussion, giving prerequisites for chemical reactions and mass/heat transfer.

A comparison of different types of ashes showed that the CFBC ash reacts readily with atmospheric $\mathrm{CO}_{2}$, but its total binding capacity is quite low due to only a moderate content of free $\mathrm{CaO}$. Therefore, a substantial part (60-80\%) of the $\mathrm{CO}_{2}$ binding capacity of the CFBC ash could be exhausted under natural conditions (Table 6). In the case of the PF ash, which is characterised by a considerable $\mathrm{CO}_{2}$-binding potential, most of the free $\mathrm{CaO}$ present in the initial ash remains unused during given periods of time - the average degree of binding was $4.5 \%$ after 1 month of disposal (Table 6). Differences in reactivity between different ash types are related to the structure and surface properties of ash particles. For instance, the SSA of the CFBC ash is up to ten times that of the PF ash. The mixture of both types of ashes exhibited a moderate $\mathrm{CO}_{2}$ binding capacity; the value of $\Delta \mathrm{CO}_{2}$ increased by $1.9 \%$, achieving an average of $23.5 \%$ of the free $\mathrm{CaO}$-based $\mathrm{CO}_{2}$-binding potential during 1 month of deposition.

Table 6. $\mathrm{CO}_{2}$-binding characteristics of different types of oil shale ashes in model conditions (average results from experiments in summer, spring/autumn and winter conditions), \% [47]

\begin{tabular}{|c|c|c|c|c|c|c|c|c|c|c|c|c|}
\hline \multirow[b]{3}{*}{ 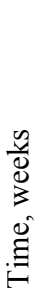 } & \multicolumn{4}{|c|}{ CFBCA } & \multicolumn{4}{|c|}{ PFA } & \multicolumn{4}{|c|}{$\begin{array}{c}\text { CFBCA and PFA mixture, } \\
1: 1\end{array}$} \\
\hline & \multicolumn{2}{|c|}{$\Delta \mathrm{CO}_{2}$} & \multicolumn{2}{|c|}{ BD* } & \multicolumn{2}{|c|}{$\Delta \mathrm{CO}_{2}$} & \multicolumn{2}{|c|}{ BD } & \multicolumn{2}{|c|}{$\Delta \mathrm{CO}_{2}$} & \multicolumn{2}{|c|}{$\mathrm{BD}$} \\
\hline & $\begin{array}{l}\breve{\bar{\Delta}} \\
\stackrel{\Xi}{\Xi}\end{array}$ & 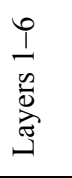 & $\overrightarrow{\breve{\Delta}}$ & 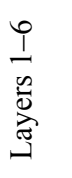 & $\begin{array}{l}\breve{\Xi} \\
\stackrel{\Xi}{\Xi}\end{array}$ & 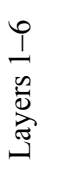 & 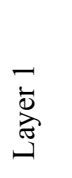 & 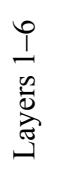 & 离 & 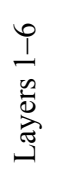 & 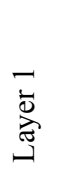 & 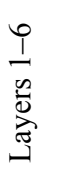 \\
\hline 0 & 0 & 0 & 0 & 0 & 0 & 0 & 0 & 0 & 0 & 0 & 0 & 0 \\
\hline 1 & 3.33 & 2.98 & 62.2 & 55.9 & 0.89 & 0.28 & 7.9 & 2.5 & 1.71 & 1.39 & 21.2 & 17.3 \\
\hline 2 & 4.02 & 3.06 & 74.7 & 57.4 & 1.40 & 0.48 & 12.3 & 4.2 & 2.14 & 1.37 & 26.5 & 16.9 \\
\hline 4 & 4.55 & 3.11 & 82.6 & 57.5 & 2.20 & 0.54 & 19.0 & 4.5 & 3.41 & 1.89 & 42.3 & 23.4 \\
\hline 8 & 5.75 & 3.12 & 105.4 & 58.2 & 3.48 & 0.89 & 30.5 & 7.7 & 5.22 & 2.19 & 64.7 & 27.1 \\
\hline
\end{tabular}

*BD - binding degree 
Based on the results of experiments performed in model conditions [27], as well as the analysis of ash samples from drill cores of the field [48], 1 ton of ash binds 9-31 kg of $\mathrm{CO}_{2}$. By implementing simple technological means, such as a periodical mixing and/or cultivation of the upper 10-15 cm layer of the ash deposit by the use of bulldozers, the amount of $\mathrm{CO}_{2}$ bound could be doubled [46], i.e. about 60,000 tons of $\mathrm{CO}_{2}$ could be bound per 1 million tons of ash, which forms $3.1 \%$ of the total $\mathrm{CO}_{2}$ emitted during combustion.

The concept of sequestration and storage of industrially produced $\mathrm{CO}_{2}$ using waste materials has been proposed by the authors [47]. Research has been directed towards utilising waste OS ash and its transportation water as sorbents for acidic gases in order to reduce its alkalinity and produce precipitated calcium carbonate (PCC) products as useful by-products $[52,53]$. It has been shown that OS ash can be completely neutralised by using $\mathrm{CO}_{2}$ from the OS combustion process $[41,54]$.

Uibu et al. [27] have studied the formation of ash stone also with respect to the construction and design (calculating the strength of the edging dams, the head of slopes and the capacity of the whole field), as well as maintenance (hardening of the surface) of waste deposits (Table 5). The compressive strength of the ash stone formed upon the hydration of the CFBC ash (3.5-4 MN $/ \mathrm{m}^{3}$ after 1 month of depositing) was initially higher, but over the course of time (4 months) the strength of the CFBC ash stone started to decrease, contrary to PF ash sample bodies, which showed an increasing compression strength (up to $2.7 \mathrm{MN} / \mathrm{m}^{3}$ ). Also, the implementation of the dense slurry method neither accelerated substantially the formation of ash stone, nor improved its properties, e.g. compression strength, $\mathrm{CO}_{2}$ binding ability, etc. The hardening of sample bodies was inhibited by the slow and uneven hydration of lime, which is mainly attributed to the slow transport of $\mathrm{H}_{2} \mathrm{O}$ molecules through the layers of other ash constituents, and reaction products $\left(\mathrm{Ca}(\mathrm{OH})_{2}, \mathrm{CaCO}_{3}\right)$ [48]. Large cracks, bumps and expansions were especially noticeable in the case of the ash stone formed from the PF ash (Fig. 9). The ash stone formed from the CFBC ash was

(a)

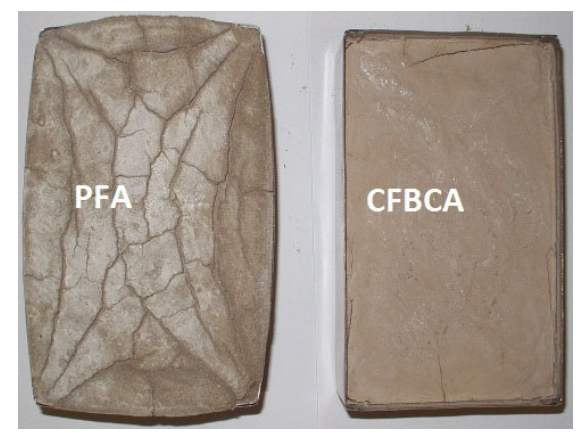

(b)

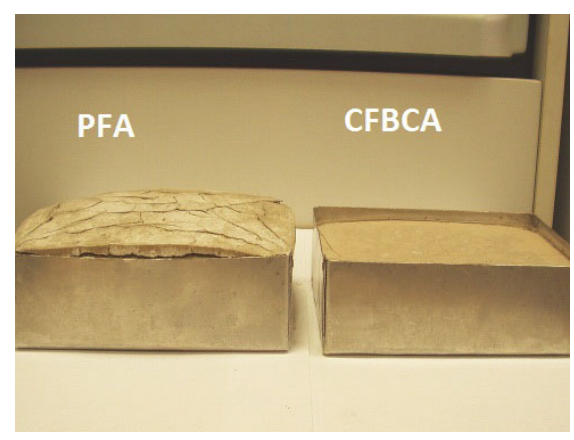

Fig. 9. Sample bodies of PF and CFBC ashes after two months of deposition in model conditions, above view (a), side view (b). 
characterised by high water absorption coefficients (80\%), which could enhance the leaching of ash components like alkaline metals and lime into the environment. Due to the relatively low solubility of $\mathrm{Ca}(\mathrm{OH})_{2}$, the hazardous effect of formation of $\mathrm{Ca}^{2+}$ and $\mathrm{OH}^{-}$ions could continue for years while in contact with fresh water.

\subsection{Diagenesis of ash in deposits}

Laboratory-scale hydration experiments [48, 49] are indicative of a rapid carbonation of the metastable portlandite by binding atmospheric $\mathrm{CO}_{2}$, which is completed under ambient conditions (allowing the free transport of $\mathrm{CO}_{2}$ ) in a few weeks or months. However, on a large scale, in waste deposits, where the contact with atmospheric $\mathrm{CO}_{2}$ is hindered by the added layers of ash, a significant, yet not complete, carbonation of portlandite is only achieved in the uppermost $0.5-1 \mathrm{~m}$ layer of the deposit, and the content of calcite decreases over about a 5-m depth interval, whereas portlandite is well preserved in the deeper parts of the ash deposit [40].

The above suggests the slow $\mathrm{CO}_{2}$ diffusion controlled carbonation of the deposit sediments which is further retarded in the upper layers of ash deposits due to the effective precipitation of calcite and other secondary minerals that will progressively block pore spaces. Similarly, the diagenesis of other secondary Ca-silicate phases is significantly subdued during a longterm deposition. However, the mineralogical data presented by Mõtlep et al. [40] suggests the dissolution of amorphous glass phases and precipitation of secondary smectite-type clay phases. The high activity of dissolved $\mathrm{Si}$ and the specifically high $\mathrm{K}(>500 \mathrm{mg} / \mathrm{l})$ [55] in the water in contact with ash would suggest the precipitation of secondary mixed-layer clays, zeolites and/or authigenic K-feldspar phases, similar to the hydration of volcanic glasses in evaporitic alkaline hypersaline or diagenetic environments. Nevertheless, secondary silicates other than smectite-type clay have not yet been identified in ash field sediments.

The slow carbonation of the ash sediment is important in retaining the stability of other primary hydration phases, especially ettringite. Portlandite dissolution equilibrium keeps the solution $\mathrm{pH}$ at about 12.3, which is well above the stability limit of ettringite ( $\mathrm{pH}$ 10.7), and in deeper or actively filled parts of ash deposits ettringite is a stable phase. However, at the calcite equilibrium ( $\mathrm{pH}$ approximately 8.2), which is attained by the carbonation of portlandite in the uppermost layers of the abandoned waste deposits, ettringite becomes unstable. At a $\mathrm{pH}$ lower than 10.7 ettringite dissolves incongruently to gypsum (6), (amorphous) Al-hydroxide and Ca-aluminate type phases; or in the presence of atmospheric $\mathrm{CO}_{2}$ into Ca-sulphate, Al-gel and calcium carbonate polymorph - aragonite or vaterite $\left(\gamma-\mathrm{CaCO}_{3}\right)$ as an intermediate phase [56-58].

$$
\begin{aligned}
\mathrm{Ca}_{6} \mathrm{Al}_{2}\left(\mathrm{SO}_{4}\right)_{3}(\mathrm{OH})_{12} \cdot 26 \mathrm{H}_{2} \mathrm{O} & +3 \mathrm{CO}_{2} \rightarrow 3 \mathrm{CaCO}_{3}+2 \mathrm{Al}(\mathrm{OH})_{3} \\
& +3 \mathrm{CaSO}_{4} \cdot 0.5 \mathrm{H}_{2} \mathrm{O}+27.5 \mathrm{H}_{2} \mathrm{O}
\end{aligned}
$$


Though the maintenance of the high $\mathrm{pH}$ and stability of ettringite is important for the geotechnical properties (strength) of ash deposits, it is also evident that the full stabilisation of deposit sediments by the carbonation and precipitation of environmentally stable calcite has only affected a limited volume of surface sediments in waste deposits, and the environmental impact of the highly alkaline ( $\mathrm{pH}$ 12-13) water draining off from ash sediment heaps will remain a problem for the decades to come.

The extremely complicated character of the transformations taking place in ash fields has been underlined. The route of transformations, including those in ash mineral composition, depends on a number of parameters, from ash chemical and phase composition to the location coordinates of the respective ash pieces in the ash field.

\section{Calculation of the quantities of $\mathrm{CO}_{2}$ emissions by natural $\mathrm{CO}_{2}$ binding in ash fields}

The results of the studies described above were taken into account while calculating the real amount of $\mathrm{CO}_{2}$ discharged into the atmosphere at OS power plants in Estonia (Regulation of the Minister of the Environment No. 94) [59]. According to the abovementioned regulations, the specific carbon emission factor for OS was calculated from equation (7) [60]:

$$
\mathrm{q}_{\mathrm{c} \text { OS }}=10\left[\mathrm{C}_{\mathrm{t}}^{\mathrm{r}}+\mathrm{k}\left(\mathrm{CO}_{2}\right)^{\mathrm{r}}{ }_{\mathrm{M}} 12 / 44\right] / \mathrm{Q}_{\mathrm{i}}^{\mathrm{r}} \text {, }
$$

where

$\mathrm{q}_{\mathrm{c}}$ os is the specific carbon emission factor, $\mathrm{tC} / \mathrm{TJ}$;

$\mathrm{C}_{\mathrm{t}}^{\mathrm{r}}$ is the carbon content in OS, \%;

$\left(\mathrm{CO}_{2}\right)_{\mathrm{M}}^{\mathrm{r}}$ is the mineral $\mathrm{CO}_{2}$ content in OS, \%;

$\mathrm{Q}_{\mathrm{i}}^{\mathrm{r}}$ is the lower heating value of OS, MJ/kg;

$\mathrm{k}$ is the factor taking into account the extent of carbonate decomposition and $\mathrm{CO}_{2}$ binding in ash fields (calculated for fuel as received).

The combustion technologies ( $\mathrm{PF}$ and $\mathrm{CFBC}$ ) currently in use differ greatly in operating conditions, which influences the extent of carbonate decomposition and has to be considered while calculating specific carbon emission. The average $\mathrm{CO}_{2}$ content in ash sediments is estimated to be $7.8 \%$ [48]. The latter was converted to dry PF ash, taking into account the mass changes due to the formation of $\mathrm{Ca}(\mathrm{OH})_{2}$ and $\mathrm{CaCO}_{3}$. The factor $\mathrm{k}$ was calculated from equation (8) [60] on the basis of an average composition of the OS used in Estonian power plants $-\mathrm{Q}_{i}^{\mathrm{d}}=9.83 \mathrm{MJ} / \mathrm{kg}$, ash content in dry $\mathrm{OS} \mathrm{A}^{\mathrm{d}}=51.33 \%$ and mineral $\mathrm{CO}_{2}$ content in dry $\mathrm{OS}\left(\mathrm{CO}_{2}\right)_{\mathrm{M}}{ }^{\mathrm{d}}=20.01 \%$ :

$$
\mathrm{k}=1-\left[\left(\mathrm{CO}_{2}{ }^{\prime \prime} / \mathrm{A}^{\prime \prime}\right) /\left(\mathrm{CO}_{2}{ }^{\prime} / \mathrm{A}^{\prime}\right)\right] \text {, }
$$

where

$\mathrm{CO}_{2}{ }^{\prime \prime}$ is the mineral $\mathrm{CO}_{2}$ content in the heated residue (ash), \%; 
$\mathrm{CO}_{2}{ }^{\prime}$ is the mineral $\mathrm{CO}_{2}$ content in the mineral part of the initial material (OS), \%;

$\mathrm{A}^{\prime}$ is the heated residue of the mineral part of the initial material (OS), \%;

$\mathrm{A}$ is the heated residue (ash content), \%.

Calculations give a general $\mathrm{k}$ value of 0.64 for the PF ash. In reality, the $\mathrm{k}$ value is a multiplication of two factors, one of which is the extent of the carbonate decomposition in boilers $\left(\mathrm{k}_{\mathrm{CO} 2}\right)$ and the other $\left(\mathrm{k}_{\text {not bound }}\right)$ takes into account the relative part of $\mathrm{CO}_{2}$ that remains unbound in ash fields from the carbon dioxide discharged from a power plant into the atmosphere. As the average value of $\mathrm{k}_{\mathrm{CO} 2}$ for $\mathrm{PF}$ boilers is 0.97 , the actual value of $\mathrm{k}_{\text {not bound }}$ would be 0.66 [61].

If in formula (7) $\mathrm{k}=0.64$, then in the case of PF boilers, the specific carbon emission $\mathrm{q}_{\mathrm{c}}$ os for Estonian OS is $27.85 \mathrm{tC} / \mathrm{TJ}$.

With the introduction of new CFBC boilers at the Estonian and Baltic power plants, the situation concerning $\mathrm{q}_{\mathrm{cos}}$ also changed. The firing temperatures in CFBC boilers are substantially lower $\left(720-800^{\circ} \mathrm{C}\right)$ than those in PF boilers $\left(>1250{ }^{\circ} \mathrm{C}\right)$, which greatly influences the intensity of carbonate decomposition [61].

According to Arro et al. [61] $\mathrm{k}_{\mathrm{CO} 2}$ can be calculated using formulas (9-12), based on the content of $\mathrm{CaO}, \mathrm{MgO}$ and carbonaceous $\mathrm{CO}_{2}$ in the ash:

$$
\begin{gathered}
\mathrm{CO}_{2 \mathrm{CaO}}=\mathrm{CaO}_{\mathrm{ash}} \cdot 0.992 \cdot \mathrm{M}_{\mathrm{CO} 2} / \mathrm{M}_{\mathrm{CaO}} \\
\mathrm{CO}_{2 \mathrm{MgO}}=\mathrm{MgO}_{\text {ash }} \cdot 0.967 \cdot \mathrm{M}_{\mathrm{CO} 2} / \mathrm{M}_{\mathrm{MgO}} \\
\mathrm{CO}_{2 \text { sum }}=\mathrm{CO}_{2 \mathrm{CaO}}+\mathrm{CO}_{2 \mathrm{MgO}} \\
\mathrm{k}_{\mathrm{CO} 2}=1-\mathrm{CO}_{2 \text { ash }} / \mathrm{CO}_{2 \text { sum }},
\end{gathered}
$$

where

$\mathrm{CO}_{2 \mathrm{CaO}}$ and $\mathrm{CO}_{2 \mathrm{MgO}}$ are the amounts of $\mathrm{CO}_{2}$ bound to $\mathrm{CaO}$ and $\mathrm{MgO}$, calculated as percentage of ash mass;

$\mathrm{CaO}_{\text {ash }}, \mathrm{MgO}_{\text {ash }}$ and $\mathrm{CO}_{2 \text { ash }}$ are the contents of $\mathrm{CaO}, \mathrm{MgO}$ and carbonaceous $\mathrm{CO}_{2}$ in ash, \%;

$\mathrm{M}_{\mathrm{CaO}}, \mathrm{M}_{\mathrm{MgO}}$ and $\mathrm{M}_{\mathrm{CO} 2}$ are the molar masses of $\mathrm{CaO}, \mathrm{MgO}$ and $\mathrm{CO}_{2}$, $\mathrm{g} / \mathrm{mol}$.

Based on the results of various experiments carried out at the Estonian and Baltic power plants during 2004-2006, the average extent of decarbonation for the total ash at the nominal boiler load fluctuated in the $\mathrm{k}_{\mathrm{CO} 2}$ range of 0.50 to 0.69 , while in most cases this value did not exceed 0.6 [61].

As the ash from CFBC boilers contains enough free lime to saturate a three- to fourfold greater volume of water with $\mathrm{Ca}(\mathrm{OH})_{2}$ than actually used in the hydraulic ash removal process, the alkalinity level of the circulating water will probably remain unchanged. It was concluded that the $\mathrm{CO}_{2}$ binding degree for the CFBC boiler ash in the hydraulic ash removal process in ash fields would remain 0.66 . 
According to the above data, $\mathrm{k}=\mathrm{k}_{\mathrm{CO} 2} \cdot \mathrm{k}_{\text {not bound }}=0.60 \cdot 0.66=0.40$. Hence, in the case of CFBC boilers, the specific carbon emission factor $\mathrm{q}_{\mathrm{c}}$ os for Estonian OS is $26.94 \mathrm{tC} / \mathrm{TJ}$.

\section{Re-cultivation and secondary use of ash deposits}

Most of the ash fields at the power plants are currently in active use for ash deposition. The first large ash field was closed at the Baltic Power Plant (ash field no 2), which had not been actively used since the 1980s because the focus has chiefly been on the development of the Estonian Power Plant. Preparations for the closure started at the beginning of 2000. The EU (European Union) Instrument for Structural Policies for Pre-Accession granted financial aid to perform the closure activities, which lasted until 2010. During the closure, more than 5 million $\mathrm{m}^{3}$ of alkaline water was neutralised with $\mathrm{HCl}$ and discharged into a nearby river. The upper level of the ash field was re-levelled, and maintenance roads were built. The entire ash field's horizontal area was seeded with grass, bushes and trees. At the same time, preparation work for the building of a wind energy park in the closed ash field was initiated. The wind farm with a capacity of $39 \mathrm{MW}$, consisting of 17 2.3 MW E82 wind turbines provided by a German Enercon company, is going to be ready for exploitation in 2012 [62].

There has been a long discussion about whether the previously described ash removal and depositing system involves the landfilling of the liquid waste, or whether the system just uses the water as a transportation media. To find a proper answer, a detailed investigation of the system was performed and environmental impacts were estimated, and international experience regarding this technology was taken into account. The dense slurry transport system was also under consideration in order to reduce the aqueous waste flows circulating in the ash transportation system, but this technology is not viable due to the specific chemical and phase composition of OS ash. It has been concluded that the hydraulic OS ash transportation and depositing system is in accordance with EU regulations (Council Directive 1999/31/EC) [45] and BAT principles (Council Directive 96/61/EC) [63], but the infiltration of the transportation water has to be monitored and preventive actions have to be put into practice if necessary. At the same time, the development towards the reuse and recycling of OS ash as a raw material for various applications is ongoing to reduce the volume of waste ash.

Over the past decades, a lot of research has been conducted on finding suitable ways for utilising ash. In the 1970-80s, OS ash was intensively used in road construction as a stabilising agent for road beds [18]. Considerable amounts of ash have been used in the production of building materials, e.g. gas concrete, and as an additive in Portland cement production [64]. Ash has also been a valuable soil liming agent in agriculture [65-67]. Recent studies have shown that ash sediment can be used as an effective filter material for 
wastewater treatment $[55,68-70]$. However, the secondary use of ash is very limited and is less than $5 \%$ of its annual production.

\section{Conclusions}

Estonia has a unique experience in the large-scale industrial utilisation of local low-grade fossil fuel - kukersite OS. About 90-93\% of Estonia's electricity demand is satisfied by OS-based power production. Using OS for heat and power generation also includes the management of chemically reactive waste ash. The combustion of OS is characterised by elevated specific carbon emissions due to the high content of mineral carbonates (limestone and dolomite) in OS. In addition to $\mathrm{CO}_{2}$ emissions, the power sector is also responsible for producing huge amounts (5-6 Mt annually) of Ca-rich (up to $25 \%$ free $\mathrm{CaO}$ ) waste ash. To transport the ash to wet open-air deposits, a hydraulic system is used in which approximately $10^{7} \mathrm{~m}^{3}$ of alkaline water ( $\mathrm{pH} \mathrm{12-13)} \mathrm{is} \mathrm{recycled} \mathrm{between} \mathrm{the} \mathrm{plant} \mathrm{and} \mathrm{the} \mathrm{sedimentary}$ pond. Distributing the highly alkaline ash dust and wastewater into the environment may lead to serious environmental problems, such as the contaminated surface and groundwater.

Disposal of OS ash of complicated phase composition in wet open-air deposits triggers a number of chemical reactions, which ultimately lead to the formation of ash stone and stabilisation of ash fields. In reality, the full stabilisation of deposit sediments is retarded by the slow hydration and $\mathrm{CO}_{2}$ diffusion, which is further slowed down by the plugging of pores and the pile-up of fresh layers of ash. As a result, the environmental impact of highly alkaline ( $\mathrm{pH} \mathrm{12-13)} \mathrm{waters} \mathrm{draining} \mathrm{off} \mathrm{from} \mathrm{ash} \mathrm{sediment} \mathrm{heaps} \mathrm{will} \mathrm{remain}$ a problem for the decades to come.

At the same time, the hydraulic open-air ash transportation and deposition system acts as a natural $\mathrm{CO}_{2}$ sink. The amount of $\mathrm{CO}_{2}$ bound is taken into account while calculating the real amount of $\mathrm{CO}_{2}$ discharged into the atmosphere by OS-fuelled power plants in Estonia.

The OS ash handling system via hydraulic transport and open-air deposition has proven to be the most feasible option, based on long-term studies and operating experience. The method is still associated with environmental risks, as huge amounts of the alkaline transportation water circulate in the system. The infiltration of the transportation water has to be monitored and preventive actions have to be put into practice if necessary. Also, the development towards the reuse and recycling of OS ash as a raw material for different applications to reduce the volume of waste ash has to be continued.

After the decommissioning, the open-air ash deposits are re-cultivated by seeding grass, bushes and trees. The second ash field of the Baltic Thermal Power Plant was recently closed down and will host a wind generation park. 17 wind generators with a total power output of $39 \mathrm{MW}$ were erected by Eesti Energia in 2011. 


\section{Acknowledgement}

The financial support from the Estonian Ministry of Education and Research (SF0142518s03, SF0140082s08, SF0180069s08), the Estonian Science Foundation (Grants No 6195, 7379, 9334), SA Archimedes (3.2.0501.10.0002) and Eesti Energia AS is gratefully acknowledged.

\section{REFERENCES}

1. World Energy Outlook 2006. International Energy Agency, 2006. (http:// www.iea.org/textbase/nppdf/free/2006/weo2006.pdf).

2. Dellantonio, A., Fitz, W. J., Repmann, F., Wenzel, W. W. Disposal of coal combustion residues in terrestrial systems: contamination and risk management. J. Environ. Qual., 2010, 39(3), 761-775.

3. Ots, A. Oil Shale Fuel Combustion. Tallinn, 2006.

4. Trikkel, A., Keelmann, M., Kaljuvee, T., Kuusik, R. $\mathrm{CO}_{2}$ and $\mathrm{SO}_{2}$ uptake by oil shale ashes: effect of pre-treatment on kinetics. J. Therm. Anal. Calorim., 2010, 99(3), 763-769.

5. Ots, A., Pihu, T., Arro, H. Influence of sulfur dioxide and hydrogen chloride on properties of oil shale ash. Oil Shale, 2005, 22(4S), 435-444.

6. Kaljuvee, T., Kuusik, R. Emission of sulphur dioxide during thermal treatment of fossil fuels. J. Therm. Anal. Calorim., 1999, 56(3), 1243-1251.

7. Kaljuvee, T., Kuusik, R., Trikkel, $\mathrm{A} . \mathrm{SO}_{2}$ binding into the solid phase during thermooxidation of blends: Estonian oil shale semicoke. J. Therm. Anal. Calorim., 2003, 72(1), 393-404.

8. Teedumäe, A., Raukas, A. The possibility of integrating sustainability into legal framework for use of oil shale reserves. Oil Shale, 2006, 23(2), 119-124.

9. World Energy Outlook 2010. Executive Summary. International Energy Agency, 2010. (http://www.iea.org/Textbase/npsum/weo2010sum.pdf).

10. Eesti statistika aastaraamat 2010. Statistical Yearbook of Estonia. Tallinn, 2010. (http://www.stat.ee/publication-download-pdf?publication id=19991).

11. Kattai, V., Saadre, T., Savitski, L. Estonian Oil Shale: Geology, Reserves, Mining Conditions. Geological Survey of Estonia, Tallinn, 2000 (in Estonian).

12. Bauert, H., Kattai, V. Kukersite oil shale. In: Geology and Mineral Resources of Estonia (A. Raukas, A. Teedumäe, eds.). Estonian Academy Publishers, Tallinn, 1997, 313-327.

13. Eesti Energia Annual Report 2010. Environmental Report. (https:// www.energia.ee/doc/pdf/concern/environmental_report_2010_eng.pdf).

14. Aarna, A. J., Lippmaa, E. T. On the structure of Baltic Basin oil shale. In: Transact. Tallinn Polytech. Inst. Tallinn, 1955, A-63, 3-50 (in Russian).

15. Dilaktorsky, N., Galibina, A., Kiiler, M. The phase composition of ash obtained by burning kukersite oil shale in pulverised mode, and the binding properties of glassy-phase oil shale ash. Research on Construction, 1961, 1, 113-127 (in Russian).

16. Vingisaar, P., Kattai, V., Utsal, K. The composition of the kukersite in the Baltic Oil Shale Basin. Proc. Estonian Acad. Sci. Geol., 1984, 33(2), 55-62 (in Russian, Summary in English). 
17. Koel, M. Estonian oil shale. Oil Shale extra, 1999. (http://www.kirj.ee/public/ oilshale/Est-OS.htm).

18. Paat, A. About the mineralogical composition of Estonian oil shale ash. Oil Shale, 2002, 19(3), 321-333.

19. Veiderma, M. Estonian oil shale - resources and usage. Oil Shale, 2003, 20(3S), 295-303.

20. Lille, Ü. Current knowledge on the origin and structure of Estonian kukersite kerogen. Oil Shale, 2003, 20(3), 253-263.

21. Golubev, N. Solid oil shale heat carrier technology for oil shale retorting. Oil Shale, 2003, 20(3S), 324-332.

22. Soone, J., Doilov, S. Sustainable utilization of oil shale resources and comparison of contemporary technologies used for oil shale processing. Oil Shale, 2003, 20(3S), 311-323.

23. Arro, H., Prikk, A., Pihu, T. Combustion of Estonian oil shale in fluidized bed boilers, heating value of fuel, boiler efficiency and $\mathrm{CO}_{2}$ emissions. Oil Shale, 2005, 22(4S), 399-406.

24. Hotta, A., Parkkonen, R., Hiltunen, M., Arro, H., Loosaar, J., Parve, T., Pihu, T., Prikk, A., Tiikma, T. Experience of Estonian oil shale combustion based on CFB technology at Narva Power Plants. Oil Shale, 2005, 22(4S), 381398.

25. Valdma, M., Tammoja, H., Keel, M. Optimization of Thermal Power Plants Operation. TUT Press, Tallinn, 2009.

26. Kuusik, R., Türn, L., Trikkel, A., Uibu, M. Carbon dioxide binding in the heterogeneous systems formed at combustion of oil shale. 2. Interactions of system components - thermodynamic analysis. Oil Shale, 2002, 19(2), 143160.

27. Uibu, M., Kuusik, R., Veskimäe, H. Seasonal binding of atmospheric $\mathrm{CO}_{2}$ by oil shale ash. Oil Shale, 2008, 25(2), 254-266.

28. Velts, O., Hautaniemi, M., Uibu, M., Kallas, J., Kuusik, R. Modelling of $\mathrm{CO}_{2}$ mass transfer and hydrodynamics in a semi-batch reactor. Journal of International Scientific Publications: Materials, Methods \& Technologies, 2010, $4(2), 68-79$.

29. Lille, Ü., Heinmaa, I., Müürisepp, A. M., Pehk, T. Investigation of kukersite structure using NMR and oxidative cleavage: On the nature of phenolic precursors in the kerogen of Estonian kukersite. Oil Shale, 2002, 19(2), 101-116.

30. Fomina, A. S., Degtereva, Z. A., Nappa, L. A., Pobul, L. Y. Chemical composition of Baltic oil shale kerogen. United Nations Symposium on the Development and Utilization of Oil Shale Resources. Tallinn: TPI Toimetised (Transact. Tallinn Polytech. Inst.), 1968.

31. Kahru, A., Põllumaa, L. Environmental hazard of the waste streams of Estonian oil shale industry: an ecotoxicological review. Oil Shale, 2006, 23(1), 53-93.

32. Arro, H., Prikk, A., Pihu, T. Calculation of composition of Estonian oil shale and its combustion products on the basis of heating value. Oil Shale, 1998, 15(4), 329-340.

33. Kattai, V. Oil Shale-Source of Oil. Geological Survey of Estonia, Tallinn, 2003 (in Estonian).

34. Development Plan of the Estonian Electricity Sector until 2018. Ministry of Economic Affairs and Communications, p. 57. (www.mkm.ee/public/ ELMAK_EN.pdf) 08.10.2010.

35. Liive, S. Oil shale energetics in Estonia. Oil Shale, 2007, 24(1), 1-4. 
36. Liblik, V., Kaasik, M., Pensa, M., Rätsep, A., Rull, E., Tordik, A. Reduction of sulphur dioxide emissions and transboundary effects of oil shale based energy production. Oil Shale, 2006, 23(1), 29-38.

37. Kuusik, R., Uibu, M., Kirsimäe, K. Characterization of oil shale ashes formed at industrial-scale boilers. Oil Shale, 2005, 22(4S), 407-420.

38. Pihu, T., Arro, H., Prikk, A., Rootamm, R., Konist, A., Kirsimäe, K., Liira, M., Mõtlep, R. Oil shale CFBC ash cementation properties in ash fields. Fuel, 2012, 93, 172-180.

39. Bityukova, L., Mõtlep, R., Kirsimäe, K. Composition of oil shale ashes from pulverized firing and circulating fluidized-bed boiler in Narva Thermal Power Plants, Estonia. Oil Shale, 2010, 27(4), 339-353.

40. Mõtlep, R., Sild, T., Puura, E., Kirsimäe, K. Composition, diagenetic transformation and alkalinity potential of oil shale ash sediments. J. Hazard. Mater., 2010, 184(1-3), 567-573.

41. Uibu, M., Velts, O., Kuusik, R. Developments in $\mathrm{CO}_{2}$ mineral carbonation of oil shale ash. J. Hazard. Mater., 2010, 174(1-3), 209-214.

42. Kuusik, R., Uibu, M., Toom, M., Muulmann, M.-L., Kaljuvee, T., Trikkel, A. Sulphation and carbonization of oil shale CFBC ashes in heterogeneous systems. Oil Shale, 2005, 22(4S), 421-434.

43. Trikkel, A., Zevenhoven, R., Kuusik, R. Modelling $\mathrm{SO}_{2}$ capture by Estonian limestones and dolomites. Proc. Estonian Acad. Sci. Chem., 2000, 49(1), 53-70.

44. Anthony, E. J., Granatstein, D. L. Sulfation phenomena in fluidized bed combustion systems. Prog. Energ. Combust. Sci., 2001, 27(2), 215-236.

45. Council Directive 1999/31/EC of 26 April 1999 on the landfill of waste. Official Journal of the European Communities. L182/1-19. (http://eur-lex.europa.eu/ LexUriServ/LexUriServ.do?uri=OJ:L:1999:182:0001:0019:EN:PDF).

46. Kuusik, R., Veskimäe, H., Kaljuvee, T., Parts, O. Carbon dioxide binding in the heterogeneous systems formed by combustion of oil shale. 1. Carbon dioxide binding at oil shale ash deposits. Oil Shale, 2001, 18(2), 109-122.

47. Uibu, M., Uus, M., Kuusik, R. $\mathrm{CO}_{2}$ mineral sequestration in oil-shale wastes from Estonian power production. J. Environ. Manage., 2009, 90(2), 1253-1260.

48. Kuusik, R., Paat, A., Veskimäe, H., Uibu, M. Transformations in oil shale ash at wet deposition. Oil Shale, 2004, 21(1), 27-42.

49. Liira, M., Kirsimäe, K., Kuusik, R., Mõtlep, R. Transformation of calcareous oil-shale circulating fluidized-bed combustion boiler ashes under wet conditions. Fuel, 2009, 88(4), 712-718.

50. Anthony, E. J., Jia, L., Wu, Y. CFBC ash hydration studies. Fuel, 2005, 84(11), 1393-1397.

51. Kaljuvee, T., Trikkel, A., Kuusik, R. Reactivity of oil shale ashes towards sulfur dioxide. 1. Activation of high-temperature ashes. Oil Shale, 1997, 14(3), 393407.

52. Kuusik, R., Uus, M., Uibu, M., Stroganov, G., Parts, O., Trikkel, A., Pepoyan, V., Terentiev, A., Kalnapenk, E. Method for neutralization of alkaline waste water with carbon dioxide consisting in flue gas. Patent EE05349, 2010.

53. Kuusik, R., Uibu, M., Uus, M., Velts, O., Trikkel, A., Veinjärv, R. Method for eliminating $\mathrm{CO}_{2}$ from flue gases by calcium compounds containing industrial wastes. Patent EE05446B1, 2011.

54. Uibu, M., Velts, O., Kuusik, R. Aqueous carbonation of oil shale wastes from Estonian power production for $\mathrm{CO}_{2}$ fixation and PCC production. In: Con- 
ference of Young Scientist on Energy Issues 2011, Kaunas, Lithuania, May 2627, 2011, 415-424.

55. Kõiv, M., Liira, M., Mander, Ü., Mõtlep, R., Vohla, C., Kirsimäe, K. Phosphorus removal using Ca-rich hydrated oil shale ash as filter material - the effect of different phosphorus loadings and wastewater compositions. Water Res., 2010, 44(18), 5232-5239.

56. Myneni, S. C. B., Traina, S. J., Logan, T. J. Ettringite solubility and geochemistry of the $\mathrm{Ca}(\mathrm{OH})_{2}-\mathrm{Al}_{2}\left(\mathrm{SO}_{4}\right)_{3}-\mathrm{H}_{2} \mathrm{O}$ system at $1 \mathrm{~atm}$ pressure and $298 \mathrm{~K}$. Chem. Geol., 1998, 148(1-2), 1-19.

57. Nishikawa, T., Suzuki, K., Ito, S., Sato, K., Takebe, T. Decomposition of synthesized ettringite by carbonation. Cement Concrete Res., 1992, 22(1), 6-14.

58. Grounds, T., Midgley, H. G., Novell, D. V. Carbonation of ettringite by atmospheric carbon dioxide. Thermochim. Acta, 1988, 135, 347-352.

59. Method for determining the amount of carbon dioxide discharged into the atmosphere. Regulation of the Minister of the Environment No. 94, 16.07.2004. (http://www.estlex.ee/tasuta/?id=7\&aktid=63734\&fd=1).

60. Kallaste, T., Liik, O., Ots, A. Possible Energy Sector Trends in Estonia. Context of Climate Change. SEI Tallinn Centre, Tallinn, 1999.

61. Arro, H., Prikk, A., Pihu, T. Calculation of $\mathrm{CO}_{2}$ emission from CFB boilers of oil shale power plants. Oil Shale, 2006, 23(4), 356-365.

62. Paist, A. Present and future of oil shale based energy production in Estonia. Oil Shale, 2011, 28(1S), 85-88.

63. Council Directive 96/61/EC of 24 September 1996 concerning integrated pollution prevention and control. Official Journal of the European Communities No L257/26-40. (http://eur-lex.europa.eu/LexUriServ/LexUriServ.do?uri=OJ:L: 1996:257:0026:0040:EN:PDF).

64. Hanni, R. Energy and valuable material by-product from firing Estonian oil shale. Waste Manage., 1996, 16(1-3), 97-99.

65. Turbas, E (ed.). Basics of Agricultural Chemistry.Valgus, Tallinn, 1971.

66. Kuldkepp, P. Basics of Plant Nutrition and Fertilization. AS Infotrükk, Tallinn, 1994.

67. Pets, L., Vaganov, P., Knoth, I., Haldna, Ü., Schwenke, H., Schnier, C., Juga, R. Microelements in oil-shale ash of the Baltic Thermoelectric Power Plant. Oil Shale, 1985, 2(4) 379-390 (in Russian, summary in English).

68. Vohla, C., Põldvere, E., Noorvee, A., Kuusemets, V., Mander, Ü. Alternative filter media for phosphorus removal in a horizontal subsurface flow constructed wetland. J. Environ. Sci. Heal. A., 2005, 40(6-7), 1251-1264.

69. Kaasik, A., Vohla, C., Mõtlep, R., Mander, Ü., Kirsimäe, K. Hydrated calcareous oil-shale ash as potential filter media for phosphorus removal in constructed wetlands. Water Res., 2008, 42(4-5), 1315-1323.

70. Veskimäe, H., Kuusik, R., Veiderma, M. Phosphorus removal from solutions by carbonaceous wastes. Proc. Estonian. Acad. Sci. Chem., 1997, 46(1/2), 21-30.

Presented by I. Aarna

Received March 5, 2012 